Review

\title{
Biotechnology of Cold-Active Proteases
}

\section{Swati Joshi and Tulasi Satyanarayana *}

Department of Microbiology, University of Delhi South Campus, New Delhi 110021, India;

E-Mail: swati.joshi.aj@gmail.com

* Author to whom correspondence should be addressed; E-Mail: tsnarayana@gmail.com;

Tel.: +91-11-24112008; Fax: +91-11-24115270.

Received: 5 March 2013; in revised form: 17 April 2013 / Accepted: 24 April 2013 /

Published: 3 May 2013

\begin{abstract}
The bulk of Earth's biosphere is cold $\left(<5^{\circ} \mathrm{C}\right)$ and inhabited by psychrophiles. Biocatalysts from psychrophilic organisms (psychrozymes) have attracted attention because of their application in the ongoing efforts to decrease energy consumption. Proteinases as a class represent the largest category of industrial enzymes. There has been an emphasis on employing cold-active proteases in detergents because this allows laundry operations at ambient temperatures. Proteases have been used in environmental bioremediation, food industry and molecular biology. In view of the present limited understanding and availability of cold-active proteases with diverse characteristics, it is essential to explore Earth's surface more in search of an ideal cold-active protease. The understanding of molecular and mechanistic details of these proteases will open up new avenues to tailor proteases with the desired properties. A detailed account of the developments in the production and applications of cold-active proteases is presented in this review.
\end{abstract}

Keywords: Extremozymes; psychrozymes; cold-active protease; metagenomics; site directed mutagenesis; x-ray crystallography

\section{Introduction}

Life exists at temperatures as low as $-20{ }^{\circ} \mathrm{C}$ in the permafrost soil and as high as $122{ }^{\circ} \mathrm{C}$ in thermal environments [1,2]. Almost $70 \%$ of our planet's surface is covered by oceans, and thus, is a major environment where the temperature is around $4{ }^{\circ} \mathrm{C}$. Polar regions constitute $15 \%$ of the Earth's surface 
and $20 \%$ of the terrestrial region of Earth is permafrost. Thus $80 \%$ of earth's surface is permanently cold with the temperatures below $5{ }^{\circ} \mathrm{C}$ [3]. All the cold geographical regions of the Earth harbor cold-adapted microorganisms, which are known as psychrophiles [4]. Modern biotech industry requires macromolecules that can function under extreme conditions. Psychrophilic and psychrotolerant microorganisms and their cold-adapted proteins and enzymes have a host of biotechnological applications [5]. Microorganisms get adapted to different niches, and thus, lead to evolution in their molecular machinery. The cold-adapted microbes are known to produce cold-active enzymes [6]. Among cold-active enzymes ( $\alpha$-amylase [7,8], lipase [9,10], aspartate transcarbamylase [11], $\mathrm{Ca}^{+} \mathrm{Zn}^{+2}$ protease, [12], citrate synthetase, [13], $\alpha$-lactamase [14], malate dehydrogenase [15], triose-phosphate isomerase [16], DNA ligase [17], xylanase [18], citrate synthase [19], metalloprotease [12], polygalacturonase [20], cellulases and xylanase [21], chitinase [22], endo-arabinanase [23], and pectinase [24]), proteases constitute an important group which have high catalytic efficiencies at lower temperatures. Proteases constitute an important class of hydrolytic enzymes that are found in all life forms as they are essential in physiological, metabolic and regulatory functions [25]. Nowadays, approximately $60 \%$ of the total enzyme market is shared by proteases in various industries, and according to a recent report from Business Communications Company (BCC 2008), the global market for industrial enzymes had been estimated to reach US $\$ 4.9$ billion by 2013 [26,27]. Proteases have found applications in diverse fields such as detergent industry, leather processing, silk degumming, food and dairy, baking, pharmaceutical industries, silver recovery from x-ray films, waste management and others. Cold-active proteases have been reported from various microorganisms, but detailed investigations on their adaptation to cold environments and structure and bioenergetics are scarce. Their application potential has not yet been exploited fully for the benefit of mankind. Microbes with high potential are still waiting in the cold and harsh niches. This review attempts to summarize the developments in cold-active proteases, and strategies that can be adapted to search for more potent and versatile cold-active proteases to suit industrial requirements.

\section{Microbes Producing Cold-Active Proteases}

Cold-active proteases are mainly sourced from microorganisms from cold habitats such as arctic regions, polar regions, deep sea and glacier soils, glacier ice, permafrost, cold desert soil, sub-Antarctic sediments, sub-glacial water, alpine regions and other cold regions on earth. The potential of psychrophiles and enzymes produced by them have been reviewed from time to time [17,28-31]. Morita [32] defined psychrophiles based on their optimal growth temperature. Organisms growing optimally at about $15{ }^{\circ} \mathrm{C}$ or below with a maximum temperature of growth at about $20{ }^{\circ} \mathrm{C}$ and the ability to survive at $0{ }^{\circ} \mathrm{C}$ are known as psychrophiles. In contrast, psychrotolerant microbes generally have optimum and maximum temperatures of growth at $20{ }^{\circ} \mathrm{C}$ or above. Psychrotolerant microbes have an optimum growth temperature between 20 and $40{ }^{\circ} \mathrm{C}$, but are also capable of growth at $0{ }^{\circ} \mathrm{C}$ [33].

Oceans cover more than $70 \%$ of Earth's surface and it is a major ecosystem with an average temperature of around $5{ }^{\circ} \mathrm{C}$, and hence, this is one of the habitats for psychrophiles. A diverse range of psychrophilic microorganism have been isolated from sea belonging to different microbial groups such as gram-negative (e.g., Pseudoalteromonas, Moraxella, Psychrobacter, Polaromonas, Psychroflexus, etc.) and gram-positive (e.g., Arthrobacter, Bacillus, Micrococcus] 
bacteria, archaea [e.g., Methanogenium, Halorubrum), yeasts (e.g., Candida, Cryptococcus) and fungi (e.g., Penicillium, Cladosporium).

Cold-active protease producing microorganisms have been isolated from different geographical regions such as Azospirillum sp. from mountain soil [34], Bacillus licheniformis from glacier soil [35] Clostridium sp. from Antarctic region [36], Colwellia sp. from sea ice [37] and sub-antarctic sediments [38], Curtobacterium luteum from glacier soil [39], Exiguobacterium sp. from cold desert soil [40], Pedobacter cryoconitis from glacier ice [41], Penicillium chrysogenum from cold marine environment [42], Pseudomonas sp. from deap sea [43], Psychrobacter proteolyticus from Antarctic krill Euphasia superba Dana [44], Serratia sp. from coastal water [45], Vibrio sp. from marine water [46] and Xanthomonas maltophilia from alpine environment [47]. Yu et al. [48] screened organisms from the sandy sediment of Nella Fjord, Eastern Antarctica [69 $22^{\prime} 6^{\prime \prime} \mathrm{S}, 76^{\circ} 21^{\prime} 45^{\prime \prime} \mathrm{E}$ ] for the cold-active hydrolytic enzymes. Out of 33 isolates screened, Sulfitobacter sp NF1-26, Photobacterium NF1-15, Pseudomonas NF1-39-1, Shewanella NF1-3, Bizionia NF1-21, Flavobacterim NF1-9, Salinibacterium NF2-5 were found to secrete proteolytic enzymes. While Kuddus et al. [49] isolated cold-active alkaline protease producing Stenotrophomonas sp. from the soil of Gangotri glacier (western Himalaya, India). Some microorganisms that are known to produce cold-active alkaline proteases are listed in Table 1.

Table 1. Microorganisms producing cold-active alkaline protease.

\begin{tabular}{|c|c|c|c|c|c|}
\hline \multirow[b]{2}{*}{ S. No. } & \multirow[b]{2}{*}{ Organisms } & \multicolumn{3}{|c|}{ Properties of the proteases } & \multirow[b]{2}{*}{ Reference } \\
\hline & & $\begin{array}{l}\text { Mol. weight } \\
\text { (kDa) }\end{array}$ & $\mathbf{T}_{\text {Opt }}\left({ }^{\circ} \mathbf{C}\right)$ & $\mathbf{p H}_{\text {Opt. }}$ & \\
\hline 1 & Alcaligenes faecalis & - & 30 & 8.8 & {$[50]$} \\
\hline 2 & Alkaliphilus transvaalensis & 30 & 40 & 12.6 & [51] \\
\hline 3 & Alteromonas haloplanktis & $74-76$ & 20 & $8-9$ & {$[52]$} \\
\hline 4 & Aspergillus ustus & 45 & 32 & 9 & [53] \\
\hline 5 & Azospirillum sp. & 48.6 & 40 & 8.5 & [34] \\
\hline 6 & Bacillus sp. & - & 30 & 9.6 & {$[54]$} \\
\hline 7 & Bacillus spp. & - & 40 & $10.5-11$ & {$[55]$} \\
\hline 8 & Bacillus amyloliquefaciens S94 & 45 & - & 10 & {$[56]$} \\
\hline 9 & Bacillus cereus & - & 20 & 9 & {$[57]$} \\
\hline 10 & Bacillus licheniformis RKK-04 & 31 & 50 & 10 & {$[58]$} \\
\hline 11 & Bacillus pumilus & - & 30 & 11.5 & [59] \\
\hline 12 & Beauveria bassiana & - & 37 & 10 & {$[60]$} \\
\hline 13 & Candida humicola & - & 37 & 10 & {$[61]$} \\
\hline 14 & Clostridium sp. & 46 & 37 & 7 & [36] \\
\hline 15 & Colwellia sp. & 60 & 35 & $8-9$ & {$[62]$} \\
\hline 16 & Colwellia psychrerythraea strain $34 \mathrm{H}$ & 71 & 19 & $6-8.5$ & {$[63]$} \\
\hline 17 & Curtobacterium luteum & 115 & 20 & 7 & [39] \\
\hline 18 & Engyodontium album & - & 25 & 11 & {$[64]$} \\
\hline 19 & Escherichia freundii & 55 & 25 & 10 & {$[65]$} \\
\hline 20 & Exiguobacterium sp.SKPB5 & 36 & 40 & 8 & {$[40]$} \\
\hline 21 & Flavobacterium YS-80 & 49 & 30 & $8-11$ & {$[66]$} \\
\hline 22 & Flavobacterium balustinum $\mathrm{P} 104$ & 70 & 40 & $7-9$ & {$[67]$} \\
\hline
\end{tabular}


Table 1. Cont.

\begin{tabular}{|c|c|c|c|c|c|}
\hline \multirow[b]{2}{*}{ S. No. } & \multirow[b]{2}{*}{ Organisms } & \multicolumn{3}{|c|}{ Properties of the Proteases } & \multirow[b]{2}{*}{ Reference } \\
\hline & & $\begin{array}{l}\text { Mol. Weight } \\
\text { (kDa) }\end{array}$ & $\mathbf{T}_{\text {Opt }}\left({ }^{\circ} \mathbf{C}\right)$ & $\mathbf{p H}_{\text {Opt. }}$ & \\
\hline 23 & Leucosporidium antarcticum 171 & 34.4 & 30 & 8 & [68] \\
\hline 24 & Pedobacter cryoconitis, & 27 & 40 & 8 & [41] \\
\hline 25 & Penicillium chrysogenum FS010 & 41 & 35 & 9 & [42] \\
\hline 26 & Planomicrobium sp. 547 & - & 35 & 9 & [69] \\
\hline 27 & Pseudoalteromonas sp. D12-004 & 34 & 35 & $7-8$ & {$[70]$} \\
\hline 28 & Pseudoalteromonas sp. NJ276 & 28 & 30 & 8 & [37] \\
\hline 29 & Pseudoalteromonas sp. P96-47 & - & 20 & 8 & [71] \\
\hline 30 & Pseudoalteromonas sp. SM9913 & 65.84 & 25 & 9 & [72] \\
\hline 31 & Pseudomonas sp Ele-2 & 45 & 40 & - & {$[73]$} \\
\hline 32 & Pseudomonas sp. & - & 20 & & [74] \\
\hline 33 & Pseudomonas strain DY-A & - & 40 & 10 & [43] \\
\hline 34 & Pseudomonas aerugenosa MTCC 7926 & - & 40 & 9 & {$[75]$} \\
\hline 35 & Pseudomonas lundensis & 48 & 30 & 10.5 & [76] \\
\hline 36 & Pseudomonas fluorescens & - & 35 & 5 & [77] \\
\hline 37 & Pseudomonas fluorescens 114. & 47 & $35-40$ & 8 & [78] \\
\hline 38 & Pycnoporus cinnabarinus ss 3 & - & 30 & 4 & [79] \\
\hline 39 & Roseobacter sp. [MMD040] & - & $37-40$ & $8-9$ & {$[80]$} \\
\hline 40 & Serratia marcescens AP3801 & 58 & 40 & $6.5-8.0$ & [81] \\
\hline 41 & Serratia marcescens TS1 & 56 & 40 & 8 & {$[82]$} \\
\hline 42 & Serratia proteamaculans 94 & 50 & $4-30$ & 8 & [83] \\
\hline 43 & Shewanella strain Ac10 & 44 & $5-15$ & 9 & [84] \\
\hline 44 & Stenotrophomonas sp. & 55 & 15 & 10 & {$[85]$} \\
\hline 45 & Stenotrophomonas maltophilia MTCC 7528 & 75 & 20 & 10 & [49] \\
\hline 46 & Streptomyces sp. & - & 30 & 10 & {$[86]$} \\
\hline 47 & Streptomyces alboniger & - & 37 & $9-11$ & [87] \\
\hline 48 & Teredinobacter turnirae & - & 25 & 7 & {$[88]$} \\
\hline 49 & Trichoderma atroviride & 24 & 25 & 6.2 & [89] \\
\hline 50 & Vibrio sp. & 35 & 40 & $8.5-9.0$ & [90] \\
\hline 51 & Vibrio sp. PA-44 & 47 & 25 & 8.6 & {$[46]$} \\
\hline
\end{tabular}

\section{Classification of Proteases}

According to the Enzyme Commission [EC] classification, proteases are members of the group 3 [Hydrolases], and sub-group 4 [hydrolyzing peptide bonds]. Proteases have been divided into two broad groups on the basis of their ability to hydrolyze $\mathrm{N}$ - or C-terminal peptide bonds [exopeptidases] or internal peptide bonds [endopeptidases]. Although exopeptidases are used in some commercial applications, endopeptidases are industrially more important than the former. Exopeptidases are subdivided as aminopeptidases that cleave the N-terminal peptide linkage and carboxypeptidases that cleave the C-terminal peptide bond.Several other features have also been used in classifying proteases into different groups such as occurrence of charged moieties at sites relative to susceptible bond [91], their $\mathrm{pH}$ optima [as acidic, neutral or alkaline], substrate specificity [collagenase, keratinase, elastase], 
or their homology to previously characterized proteases such as trypsin, pepsin and others [trypsin-like, pepsin-like]. Morihara [92] classified serine proteases as trypsin-like proteinases, alkaline proteinases, Myxobacter $\alpha$-lytic proteinases and staphylococcal proteinases. Hartley et al. [93] classified endoproteases into four groups on the basis of their active site and sensitivity to various inhibitors. The properties of the enzymes are summarized in Table 2.

\section{Optimization of Fermentation Conditions for Production of Cold-Active Proteases}

Proteases produced by microorganisms are predominantly extracellular in nature and are greatly affected by nutritional and physicochemical factors. Optimization of different media components can greatly affect the production cost and can lead either to profit or loss in an industry based on production of bioactive compounds by microorganisms. Proper balance of various media components determines the utilization of each component. In order to have a cost effective method of enzyme production, optimization of various media components is needed. Importance of this step is revealed by the fact that $30 \%-40 \%$ of production cost of industrial enzymes is estimated to be the cost of the growth medium [94]. No single medium can be used for production of protease from different psychrotrophic microbes. Each microorganism has its own specific idiosyncratic, physicochemical and nutritional requirements for the production of maximum enzyme titer. Therefore, it is necessary to optimize the production conditions for the strain of interest. Protease production by psychrotrophic microorganisms is affected by media components such as changes in $\mathrm{C} / \mathrm{N}$ ratio, presence or absence of some easily metabolizable sugars such as glucose and sucrose in the production medium. Casein was the best nitrogen source, but the presence of carbohydrates like glucose, sucrose and lactose led to catabolic repression of protease production in Colwellia sp. [37]. Metal ions in the surrounding environment affect the growth of the organisms. Some having positive effect and some inhibits the growth of the organism. It is critical to find out which metal ion supports both the growth of the organism under study and the protease production. In Stenotrophomona sp., the enzyme production was enhanced by $\mathrm{Cu}^{2+}[126.8 \%]$ and $\mathrm{Cr}^{2+}[134.6 \%]$, but $\mathrm{Co}^{2+}$ reduced it [43.5\%]. The other heavy metals such as $\mathrm{Hg}^{2+}, \mathrm{Cd}^{2+}$ and $\mathrm{Zn}^{2+}$ had no significant effect [49]. Vazquez et al. [95] reported that increasing concentrations of calcium chloride $\left[0\right.$ to $\left.0.3 \mathrm{~g} \mathrm{l}^{-1}\right]$ in culture media enhanced protease production in Stenotrophomonas maltophilia; the highest titre was attained after $36 \mathrm{~h}$ of growth.

Most of the proteolytic enzymes are produced and secreted in late exponential growth phase [96]. Stenotrophomona sp. has been reported to secrete maximum enzyme at $120 \mathrm{~h}$ [49]. While the enzyme production by Pedobacter cryoconitis attained a peak in $72 \mathrm{~h}$, and thereafter, there was plateau in enzyme production [41]. Pseudomonas sp. strain DY-A produced maximum protease after $30 \mathrm{~h}$ incubation [43]. In case of Pseudomonas sp. strain DY-A protease, $10{ }^{\circ} \mathrm{C}$ was found optimum both for growth and protease production. Temperature change to $25{ }^{\circ} \mathrm{C}$ reduced both the growth and protease production [43]. In Stenotrophomona sp., a high protease titre [56.2 U/ml] was attained at $20{ }^{\circ} \mathrm{C}$. This observation suggested that high enzyme titers could be produced in the temperature range between 15 and $25{ }^{\circ} \mathrm{C}$ [49]. Pedobacter cryoconitis produced maximum enzyme at $15{ }^{\circ} \mathrm{C}$, although $44 \%$ of the maximum enzyme titer was also attained at $1^{\circ} \mathrm{C}$ [41]. 
Table 2. Classification and biochemical characteristics of endoproteases.

\begin{tabular}{|l|c|c|c|c|c|l|l|}
\hline \multicolumn{1}{|c|}{ Endoprotease } & EC No. & Mol. Mas Range (kDa) & $\mathbf{p H}_{\text {Opt. }}$ & $\left.\mathbf{T}_{\text {Opt. }}{ }^{\circ} \mathbf{C}\right)$ & $\begin{array}{l}\text { Metal Ion } \\
\text { Required }\end{array}$ & Active Site a Residues & Major Inhibitor(s) \\
\hline $\begin{array}{l}\text { Aspartic or } \\
\text { Carboxyl proteases }\end{array}$ & 3.4 .23 & $30-45$ & $3-5$ & $40-55$ & $\mathrm{Ca}^{2+}$ & Aspartate or cysteine & Pepstatin \\
\hline $\begin{array}{l}\text { Cysteine or thiol } \\
\text { proteases }\end{array}$ & 3.4 .22 & $34-35$ & $2-3$ & $40-55$ & - & Aspartate or cysteine & Indoacetamide, $p$-CMB \\
\hline Metallo- proteases & 3.4 .24 & $19-37$ & $5-7$ & $65-85$ & $\begin{array}{l}\mathrm{Zn}^{2+}, \\
\mathrm{Ca}^{2+}\end{array}$ & $\begin{array}{l}\text { Phenylalanine or } \\
\text { leucine }\end{array}$ & $\begin{array}{l}\text { Chelating agents such as } \\
\text { EDTA, EGTA }\end{array}$ \\
\hline Serine proteases & 3.4 .21 & $18-35$ & $6-11$ & $50-70$ & $\mathrm{Ca}^{2+}$ & $\begin{array}{l}\text { Serine, histidine and } \\
\text { aspartate }\end{array}$ & $\begin{array}{l}\text { PMSF, DIFP, EDTA, } \\
\text { soybean trypsin inhibitor, } \\
\text { phosphate buffers, indole, } \\
\text { phenol, triamino acetic acid }\end{array}$ \\
\hline
\end{tabular}




\section{Purification of Cold-Active Proteases}

Proteases have been screened and purified from different sources. Different strategies have been employed for purifying cold-active proteases from diverse sources. The purification strategies used for purifying cold-active proteases from different sources are presented in Table 3. Proteases secreted into the medium are first concentrated by using methods such as ultrafiltration [96-98], ammonium sulphate $[36,39,42,43]$ or acetone precipitation [68,81]. A few methods involve use of PEG [72] and lyophilization [69]. After concentrating protein, further purification is achieved either by single technique or by combining two different methods. Ion exchange chromatography is a method of choice in maximum cases. DEAE [diethyl amino ethyl] and CM [carboxy methyl] group containing matrices are mainly used to which protein molecules get adsorbed and can be eluted either by $\mathrm{pH}$ change or change in ionic strength of the eluent buffer.

Affinity chromatography technique is also a successful method of purification but labile nature of affinity ligands and higher cost are limiting factors. Hydrophobic interaction chromatography [HIC] and gel filtration chromatography have also been used extensively for protease purification either at an early to middle stage or in the final stage. Sephacyl, Superdex, Superose and Topopearl gels are most commonly used for filtration purpose. Zambare et al. [99] used various chromatographic techniques to purify protease from $P$. aeruginosa MCM B-327 and determined its molecular weight (Figure 1).

Figure 1. Native-PAGE of crude and purified protease from P. aeruginosa MCM B-327. (A) silver stained gel; (B) zymogram of protease with casein; (C) plot of $\mathrm{R}_{\mathrm{f}}$ values versus standard molecular weights [99].

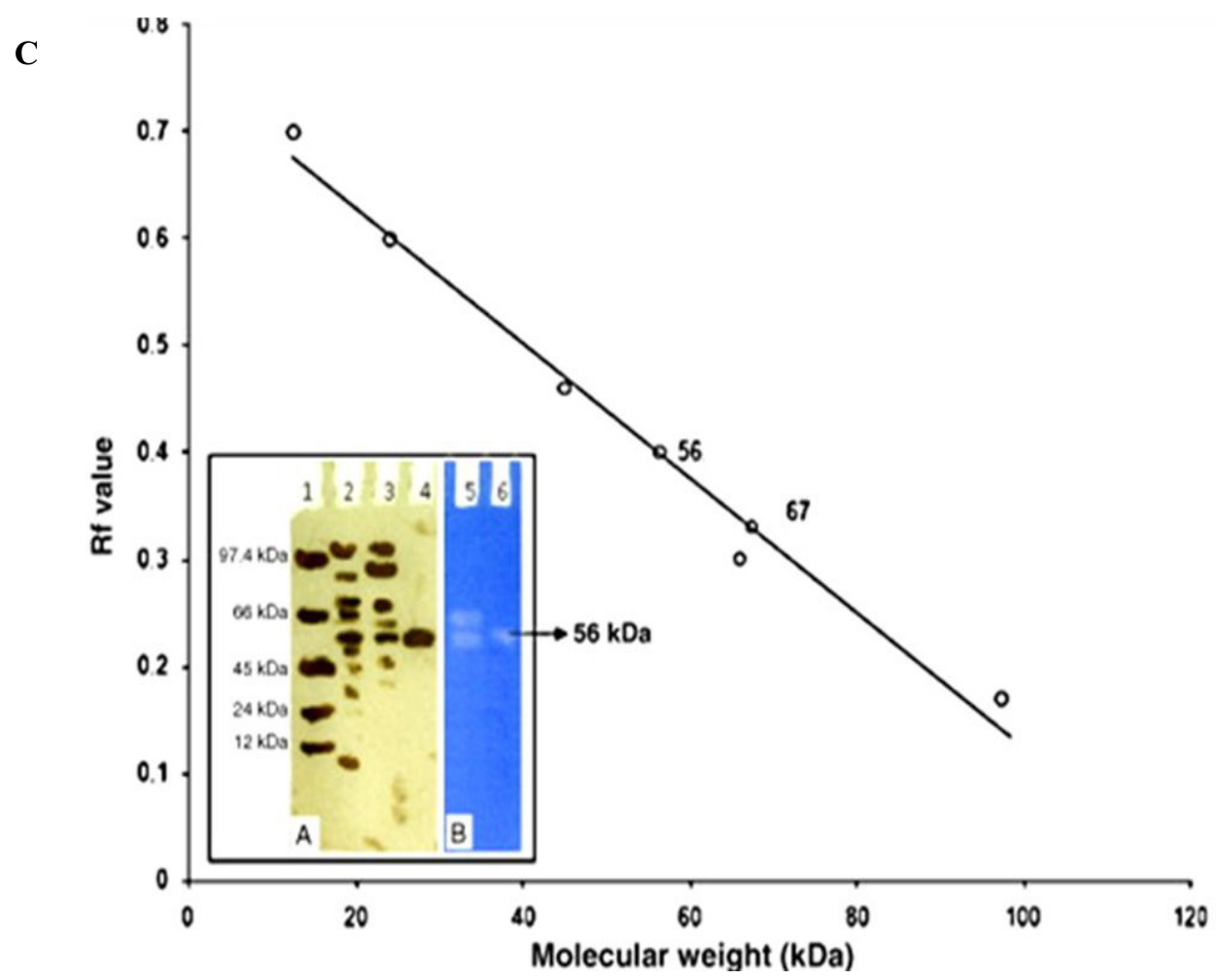


Table 3. Strategies used for purification of cold-active proteases.

\begin{tabular}{|c|c|c|c|c|c|}
\hline Protease Source & Protease Type & Concentration Method & Column Matrices & $\begin{array}{c}\text { Fold } \\
\text { Purification }\end{array}$ & References \\
\hline Alkaliphilus transvaalensis & Serine protease & Amicon Ultra-15 & $\begin{array}{l}\text { DEAE Toyopearl 650M resin,CM- } \\
\text { Toyopearl 650M }\end{array}$ & 96 & {$[58]$} \\
\hline Clostridium species & Serine-type metalloenzyme & Ammonium sulfate precipitation & Sephadex G-100 & 12.7 & {$[36]$} \\
\hline $\begin{array}{l}\text { Colwellia psychrerythraea strain } \\
34 \mathrm{H} .\end{array}$ & Aminopeptidase & - & Sepharose Q,Hydroxyapatite,Resource Q & 460 & {$[63]$} \\
\hline $\begin{array}{l}\text { Curtobacterium luteum MTCC } \\
7529\end{array}$ & Metalloprotease & $\begin{array}{l}\text { Ammonium sulphate } \\
\text { precipitation }\end{array}$ & DEAE- Cellulose & 34.1 & {$[39]$} \\
\hline Escherichia freundii, & Neutral serine protease & Ammonium sulfate precipitate & $\begin{array}{l}\text { CM-cellulose, DEAE-Sephadex A-50, } \\
\text { Sephadex G-100 }\end{array}$ & - & {$[65]$} \\
\hline Leucosporidium antarcticum 171 & Serine proteinase & Acetone precipitation & $\begin{array}{l}\text { Sephadex G-75,Diethylaminoethyl- } \\
\text { Sephacel,Sephacryl S-100 }\end{array}$ & 1,568 & {$[68]$} \\
\hline Oerskovia xanthineolytica TK-1 & Serine protease & Ultrafiltration & Phenyl-Sepharose CL-4B, DEAE-Sephacel & 39.6 & [97] \\
\hline Pedobacter cryoconitis & Metalloprotease & - & SP Sepharose,Syn-Chropak CM300 & - & {$[39]$} \\
\hline Penicillium chrysogenum FS010 & Serine protease & Ammoniumsulfate precipitation & DEAE Sepharose,Sephadex G-100 & 103.2 & [42] \\
\hline Planomicrobium species & Serine protease & $\begin{array}{l}\text { Ammonium sulfate precipitation, } \\
\text { Lyophilization }\end{array}$ & DEAE-52 & - & {$[69]$} \\
\hline Pseudoalteromonas sp. NJ276 & Serine protease & Ammonium sulfate precipitation & DEAE-Sephadex A50,Sephadex G-75 & 22.5 & [37] \\
\hline Pseudoalteromonas sp. SM9913 & Serine protease. & $\begin{array}{l}\text { Ammonium sulfate precipitation, } \\
\text { PEG } 2000 .\end{array}$ & Sephadex G100 & - & {$[53]$} \\
\hline $\begin{array}{l}\text { Pseudomonas aeruginosa IFO } \\
3455\end{array}$ & Metalloprotease & - & QAE-agarose & - & {$[74]$} \\
\hline P. fluorescence 114 & Neutral metalloprotease & Ammoniumsulfate precipitation & $\begin{array}{l}\text { DEAE Toyopearl } 650 \text { M, Superdex } 200 \\
\text { HR } 10 / 30\end{array}$ & - & {$[78]$} \\
\hline Pseudomonas strain DY-A & Serine protease & Ammonium sulfate precipitation, & $\begin{array}{l}\text { DEAE Sepharose CL-6B, } \\
\text { Sephadex G-100 }\end{array}$ & 84.2 & {$[43]$} \\
\hline Serratia marcescens AP3801 & Metalloprotease & Ammonium sulfate precipitation & Sephacryl S-100, Q Sepharose & 0.48 & {$[62]$} \\
\hline
\end{tabular}


Table 3. Cont.

\begin{tabular}{|c|c|c|c|c|c|}
\hline Protease Source & Protease Type & Concentration Method & Column Matrices & $\begin{array}{c}\text { Fold } \\
\text { Purification }\end{array}$ & References \\
\hline S. marcescens TS1. & Metalloprotease & $\begin{array}{l}\text { Ammonium sulphateation, } \\
\text { acetone precipitation }\end{array}$ & DEAE-cellulose & - & {$[82]$} \\
\hline S. proteamaculans & Trypsin-like protease & Ultrafiltration & Q-Sepharose,BPTI-Sepharose & - & [98] \\
\hline S. proteamaculans & $\begin{array}{l}\text { Serine trypsin-like and } \\
\text { Zn-dependent protease. }\end{array}$ & - & BPTI-Sepharose & - & {$[100]$} \\
\hline S. proteamaculans 94 & Cysteine protease & - & $\begin{array}{l}\text { Arg-Silochrom Z-Gly-DL-Pro-Gly-Silochrom, } \\
\text { Superise } 12 \text { HR 10/30 column }\end{array}$ & 3433 & {$[83]$} \\
\hline Shewanella strain Ac10 & Alkaline serine protease & - & Bacitracin-Sepharose column & & [84] \\
\hline Stenotrophomonas maltophilia & Serine proteases & Ultrafiltration & S-Sepharose & - & [101] \\
\hline Stenotrophomonas sp. & Alkaline protease & Ammonium sulfate precipitation & DEAE-Sepharose & 18.45 & [85] \\
\hline Marine psychrophilic strainPA-43 & Serine peptidase & - & Q Sepharose, Sephacryl S-300, PBE 94 & 25.0 & [102] \\
\hline Vibrio sp. PA-44 & $\begin{array}{l}\text { subtilisin-like } \\
\text { proteinase }\end{array}$ & Ammonium sulfate precipitation & $\begin{array}{l}\text { N-carbobenzoxy-d-phenylalanyl- } \\
\text { triethylenetetramine-Sepharose, } \\
\text { phenyl-sepharose }\end{array}$ & - & [46] \\
\hline
\end{tabular}




\section{Properties of Cold-Active Proteases}

\subsection{Temperature}

Protease produced from Stenotrophomonas maltophilia MTCC 7528 is optimally active at $20{ }^{\circ} \mathrm{C}$ and the activity of the enzyme is retained even after repeated freez-thaw cycles [49]. M1 aminopeptidase (designated ColAP) produced by the marine psychrophilic bacterium Colwellia psychrerythraea strain 34H exhibited optimum activity at $19^{\circ} \mathrm{C}$ [63]. Zhu et al. [42] reported optimal temperature for protease produced by Penicillium chrysogenum FS010 was $35{ }^{\circ} \mathrm{C}$, about $10-15{ }^{\circ} \mathrm{C}$ lower than normally used industrial protease. The enzyme showed relatively high activity between 15 and $35{ }^{\circ} \mathrm{C}$. It retained $41 \%$ of proteolytic activity at $0{ }^{\circ} \mathrm{C}$. Protease produced by Pedobacter cryoconitis showed optimum temperature for activity was $40{ }^{\circ} \mathrm{C}$. Activity was significantly reduced at $50{ }^{\circ} \mathrm{C}$, and total inactivation occurred at $60{ }^{\circ} \mathrm{C}$. High activity $(28 \%-79 \%$ of the maximum activity) was detected at $20-35{ }^{\circ} \mathrm{C}[41]$.

\section{2. $p H$}

The activity of any enzyme is greatly affected by the $\mathrm{pH}$ of the reaction mixture. Each enzyme has its own optimum $\mathrm{pH}$ at which is shows maximum activity. Protease fall into different classes based on their pH optima. An alkaline protease isolated from Stenotrophomonas maltophilia MTCC 7528 has been shown to be optimally active at $\mathrm{pH} 10$ [49]. Protease produced by Pseudoalteromonas sp. NJ276 has optimum enzyme activity at $\mathrm{pH} 8.0$. About 31 and $38 \%$ of its optimum activity is detectable at $\mathrm{pH}$ 5.0 and 11.0, respectively [35]. Protease of Pseudomonas sp. strain DY-A showed a broad pH profile ( $\mathrm{pH}$ 6.0-12.0) for casein hydrolysis and highest activity between $\mathrm{pH} 8.0$ and 10.0. The highest stability of this protease was recorded at $\mathrm{pH} 10.0$ [43].

\subsection{Metal Ions}

Cold-active protease from Pseudoalteromonas sp. NJ276 was partially inhibited by metals such as $\mathrm{Mg}^{2+}, \mathrm{Ca}^{2+}, \mathrm{Cu}^{2+}, \mathrm{Zn}^{2+}, \mathrm{Ba}^{2+}, \mathrm{Fe}^{2+}, \mathrm{Pb}^{2+}$ and $\mathrm{Mn}^{2+}$. The enzyme was stable after incubation for $1 \mathrm{~h}$ in the presence of $2 \mathrm{M} \mathrm{NaCl}$, moreover, $56.5 \%$ of the maximum activity was detected in the presence of high-salt concentrations (up to $3 \mathrm{M} \mathrm{NaCl}$ ) [37]. Zeng et al. [43] reported that total activity of protease from Pseudomonas sp. strain DY-A production medium was increased by $30 \%$ in the presence of $\mathrm{Ca}^{2+}$ and $\mathrm{Mg}^{2+}(10 \mathrm{mM})$. These metal ions enhanced the enzymatic activity slightly $(8 \%)$ and had an important role in enzyme stability. Among the cations tested, $\mathrm{Co}^{2+}, \mathrm{Cu}^{2+}$ and $\mathrm{Zn}^{2+}$ inhibited the enzymatic activity, while $\mathrm{Fe}^{3+}, \mathrm{Mn}^{2+}, \mathrm{K}^{+}, \mathrm{Li}^{+}, \mathrm{Hg}^{+}, \mathrm{Ag}^{+}$had no observable effect on enzymatic activity [43]. Penicillium chrysogenum FS010 protease activity was increased by the addition of $\mathrm{Ca}^{2+}$, $\mathrm{Na}^{+}, \mathrm{Mg}^{2+}, \mathrm{K}^{+}, \mathrm{NH}_{4}{ }^{+}$, while $\mathrm{Cu}^{2+}, \mathrm{Co}^{2+}, \mathrm{Fe}^{3+}$ and EDTA inhibited the enzyme activity. The inhibitory effects of $\mathrm{Fe}^{3+}$ and EDTA were the strongest [43]. $\mathrm{Cu}^{2+}$ and $\mathrm{Fe}^{3+}$ showed strong inhibitory effect on Ps5 metalloprotease of Pseudomonas lundensis, while $\mathrm{Co}^{2+}, \mathrm{Fe}^{2+}, \mathrm{Mn}^{2+}, \mathrm{Al}^{3+}$ reduced enzyme activity to $32 \%-14 \%$ [76]. Yang et al. [76] suggested that there could be a new catalytic pathway for reaction mechanism of Ps5 protease as contrary to other metalloproteases it showed inhibition by $\mathrm{Zn}^{2+}$. The activity of ColAP was strongly inhibited by $\mathrm{Zn}^{2+}$ and $\mathrm{Mn}^{2+}$, while $\mathrm{Ca}^{2+}$ was slightly inhibitory, 
$\mathrm{Mg}^{2+}$ stimulated activity at $10 \mathrm{mM}$ or higher, which is almost equivalent to the concentration found in seawater [63].

\subsection{Effect of Inhibitors and Other Reagents}

Cold-active protease of Pseudoalteromonas sp. NJ276 was inhibited by phenylmethylsulfonylfluoride [PMSF], sodium dodecyl sulfate [SDS], urea, thiourea, dithiothreitol [DTT], ethylenediaminetetraacetic acid [EDTA] and ethylene glycol tetraacetic acid [EGTA] but cystein protease inhibitor E-64 had no effect on the activity [37]. Pseudomonas sp. strain DY-A protease was completely inhibited by $1 \mathrm{mM}$ of diisopropyl fluorophosphate (DFP), PMSF and 4-(2-Aminoethyl) benzenesulfonyl fluoride hydrochloride [AEBSF] which indicates that it was a serine protease. The enzyme was found resistant to thiol reducing agents such as DTT $(10 \mathrm{mM})$ and $\beta$-mercaptoethanol [ $\beta$-ME] $(5 \%)$, suggesting that disulfide bonds were not involved in preserving proteolytic activity. The enzyme was found sensitive to urea $(4 \mathrm{M})$, SDS $(1 \%)$ and guanidine-HCl $(1 \mathrm{M})$, indicating that hydrogen bonds played an important role in preserving the enzyme activity [43]. Seventy percent activity of cold-active metalloprotease Ps5 of Pseudomonas lundensis HW08 was inhibited by 10mM PMSF [76], indicating that it was a serine protease. Only $40 \%$ of the maximum activity was left after treatment with $1 \mathrm{mM}$ EDTA while EGTA had no significant effect on activity of Ps5 protease. Ps5 protease exhibited an interesting property of stimulation of activity $124 \%$ at $1.0 \%$ of $\mathrm{H}_{2} \mathrm{O}_{2}$, and retained $73 \%$ activity on increasing $\mathrm{H}_{2} \mathrm{O}_{2}$ concentration to $10 \%$. Moreover $10 \%$ urea stimulated enzyme activity, but it lost the activity completely in the presence of anionic detergent SDS even at 1\%. Hustan et al. [63] reported that the activity of ColAP was not affected significantly by PMSF, but inhibited by $10 \mathrm{mM}$ DTT (a reducing agent) and EDTA (a metal-chelating agent).

\subsection{Catalytic Efficiencies}

Although the environmental and physiological effects on microorganisms dwelling in cold environments have been understood fairly well, the mechanistic details that allow enzymatic reactions in the cold niches have not been understood adequately. Cold temperatures lead to exponential decreases in rates of chemical reactions, as clear by the Arrhenius equation, and also lead to increase in the compact folding of proteins, and thus restricting the conformational ease needed for catalysis [102]. Despite these setbacks, cold-active enzymes have evolved in nature. In contrast to mesophilic enzymes, these enzymes exhibit three general distinguishing features: a higher specific activity $\left[k_{\text {cat }}\right]$ or catalytic efficiency $\left[i . e ., k_{\text {cat }} / K_{\mathrm{m}}\right]$ at temperatures between 0 and $30{ }^{\circ} \mathrm{C}$, a lower optimal temperature for activity, and reduced stability due to temperature rise and denaturating agents [103]. Kinetic parameters like $K_{\mathrm{m}}$ and $k_{\text {cat }}$ have been studied in several psychrophilic enzymes and compared with their mesophilic and thermophilic counterparts [14,103]. Enzymes usually buried in huge amount of substrate tend to optimize their $k_{\text {cat }}$ rather than $K_{\mathrm{m}}$ [14] for efficient functioning at low temperatures. Cold-active protease from Clostridium species isolated from Schirmacher oasis, Antarctica showed an increase in $K_{\mathrm{m}}$ with decrease in temperature which appears to be a characteristic that indicates a weak substrate binding which in turn lowers the activation energy [36]. This strategy to improve catalytic efficiency at low temperature has been adopted by many cold-active enzymes from Antarctic bacteria including alpha amylase from Alteromonas haloplanctis [104] and $\beta$-lactamase from Psychrobacter 
immobilis [14]. The Clostridium protease also exhibited a $Q 10$ value (1.91) which is much lower than that observed for most mesophilic enzymes, which are in the order of 2 to 3 [14]. True psychrophilic enzymes are more flexible in structure and are invariably thermolabile. Despite displaying adaptational features of a cold-active enzyme like low $Q 10$ value and increased $K_{\mathrm{m}}$ at low temperatures, protease from Clostridium has been moderately thermostable [36].

The Michaelis-Menten constant $\left[K_{\mathrm{m}}\right]$ and catalytic efficiency $\left[k_{\mathrm{cat}} / K_{\mathrm{m}}\right]$ values for protease from Pseudoalteromonas sp. NJ276 were $0.41 \mathrm{mM}$ and $45 \mathrm{~s}^{-1} \mathrm{mM}^{-1}$, respectively at $35{ }^{\circ} \mathrm{C}$. The enzyme retained $54 \%$ of $k_{\text {cat }}$ and $k_{\text {cat }} / K_{\mathrm{m}}$ at $0{ }^{\circ} \mathrm{C}$. The activation energy of the protease was $34.8 \mathrm{~kJ} \mathrm{~mol}^{-1}$ [37].

Huston el al. [63] reported the highest specific activity [ $\left.k_{\text {cat }}\right]$ for Colwellia psychrerythraea strain $34 \mathrm{H}$ cold-active protease (ColAP) at $19{ }^{\circ} \mathrm{C}$. The highest $k_{\text {cat }} / K_{\mathrm{m}}$ value for ColAP was also recorded at $19{ }^{\circ} \mathrm{C}\left(5.0 \mathrm{~s}^{-1} \mathrm{mM}^{-1}\right)$, and $44 \%$ of this was retained at $9{ }^{\circ} \mathrm{C}$ which is the optimum growth temperature for the strain $34 \mathrm{H}$.

\subsection{Substrate Spectrum}

Proteases generally exhibit broad substrate specificity and are found active against both synthetic substrates and native proteins. Zeng et al. [43] reported Pseudomonas sp. strain DY-A protease displayed high activity towards N-succinyl-Ala-Ala-Pro-Phe-p-nitroanilide and N-succinyl-Ala-AlaPro-Leu-p-nitroanilide, which are well-known substrates for chymotrypsin but showed no activity towards N-Succinyl-Ala-Ala-Pro-Asp-p-nitroanilide, N-Succinyl-Ala-Ala-Ala-p-nitroanilide, N-Succinyl-Gly-Phe-p-nitroanilide. MCP-3 protease from Pseudoalteromonas sp. SM9913 displayed a broad substrate specificity and hydrolysed AAPF [N-Succinyl-Ala-Ala-Pro-Phe-p-nitroanilide] and partially hydrolyzed AAPL[N-Succinyl-Ala-Ala-Pro-Leu-p-nitroanilide], AAPK [N-Succinyl-AlaAla-Pro-Lys-p-nitroanilide], AAPR [N-Succinyl-Ala-Ala-Pro-Arg-p-nitroanilide], FAAF [N-SuccinylPhe-Ala-Ala-Phe-p-nitroanilide] and FVR [N-Benzoyl-Phe-Val-Arg-p-nitroanilide] [105]. The protease from Pseudomonas fluorescens hydrolyzed various proteins with preference for milk proteins, caseins, as substrates [106]. Urea-Hb (urea-denatured haemoglobin) is the preferred substrate of the Antarctic yeast Leucosporidium antarcticum 171 proteinase lap2. The activity against native $\mathrm{Hb}$ and casein was found $60 \%-70 \%$ lower. The subtilase showed poor activity on elastin [68]. Psychrotrops have been reported to preferentially use synthetic substrates with proline at position P2 and an aromatic residue rather than an aliphatic residue at position P1 [63,102,107]. Protease from Shewanella strain PA- 43 displayed high activity towards N-succinyl AAPF p-nitroanilide. N-succinyl AAPL p-nitroanilide was also a relatively good substrate but showed reduced activity for N-succinyl AAVA p-nitroanilide. $\mathrm{N}$-succinyl GGF p-nitroanilide, N-succinyl AAA p-nitroanilide and N-succinyl AAPD p-nitroanilide were poor substrates, and there was no activity with N-succinyl AAV p-nitroanilide, N-succinyl GFG p-nitroanilide, N-succinyl L-Phe p-nitroanilide, or N-benzoyl DL-Arg p-nitroanilide [102]. Acidic protease from psychrotrophic yeast Candida humicola hydrolyzed poly-L-Ala, poly-L-Ser, poly-L-Phe, and poly-L-Glu but was more active on native proteins such as BSA, casein, gelatin, and melittin [61]. Flavobacterium balustinum protease displayed endoprotease activity with $\mathrm{N}$ Suc- AAPL-p-nitroanilides, whereas, there was no exoprotease activity of protease when L-Ala-pNA and L-Phe-pNA was used as substrate [50]. As proteases from psychrotrophs have been 
found to exhibit wide range of substrate specificity, they can be utilized for bioremediation of industrial and domestic waste at ambient temperature.

\section{Cloning and Expression of Cold-Active Proteases}

Recombinant DNA technology has revolutionized the enzyme industry by providing a means for making the enzyme production process very economical. Till date very few attempts have been made in cloning of cold-active proteases and expression in heterologous or homologous hosts. Ni et al. [108] reported cloning of a 1248 bp long alkaline protease gene ORF (encoding a $42.9 \mathrm{kDa}$ protein) from marine yeast Aureobasidium pullulans HN2-3 into surface display vector pINA1317-Y1CWP110. This gene (ALP2) was heterologously expressed in cells of Yarrowia lipolytica. The recombinant $Y$. lipolytica cells displayed protease on its surface and were able to produce bioactive peptides from different sources of proteins. Khairullin et al. [98] sequenced and cloned a 78kDa novel trypsin like protease (PSP) from Serratia proteamaculans. The protease was cloned in E. coli expression vector pET23b (+) and trsansformed into E. coli BL21 [DE3] expression strain. Recombinant protein was purified using $\mathrm{Ni}^{2+}$-NTA agarose column. The yield of expressed His6-PSP was $150 \mathrm{mg}$ from $100 \mathrm{~g}$ of biomass. Yan et al. [105] cloned cold-adapted halophilic proteases from deep-sea psychrotolerant bacterium Pseudoalteromonas sp. SM9913. Yan et al. cloned the protease gene into pET22b (+) and expressed the gene as active protein in E. coli BL21 [DE3] cells. The recombinant protein was purified from fermentation broth as a multidomain protein containing one catalytic domain and two PPC domains which were further characterized using purified recombinant protein. Wintrode et al. [109] used cloning and expression technique to study the reversal of the properties of a mesophilic subtilisin like protease from Bacillus sphaericus to a protease resembling more to a psychrophilic protease. Directed laboratory evolution approach used by Wintrode resulted in generation of a protease which showed rate constant $\left[k_{\text {cat }}\right]$ at $10{ }^{\circ} \mathrm{C} 6.6$ times and a catalytic efficiency $\left[k_{\text {cat }} / K_{\mathrm{m}}\right] 9.6$ times that of wild type. Its half-life at $70{ }^{\circ} \mathrm{C}$ is 3.3 times less than wild type. Wintrode et al. (109) used E. coli-Bacillus shuttle vector pSPH2R and a protease deficient Bacillus strain DB 428 for their study. DNA library was prepared in E. coli HB101 cells and then transformation of Bacillus competent cells was performed. Taguchi et al. [110] also took assistance of cloning and expression technology to improve psychrophilic features of a cold-active protease. The mutant subtilisin m-63 showed $k_{\text {cat }} / K_{\mathrm{m}}$ value $100 \%$ higher than that of the wild type at $10{ }^{\circ} \mathrm{C}$ when $N$-succinyl-L-Ala- L-Ala-L-Pro-L-Phe-pnitroanilide was used as a substrate. This cold adaptation resulted due to three mutations, Val to Ile at position 72 [V72I], Ala to Thr at position 92 [A92T], and Gly to Asp at position 131 [G131D], and it was observed that an enhancement in substrate affinity was mostly responsible for the increased activity. Taguchi et al. [110] used pUC18 and pHY300PLK expression vectors for E. coli and Bacillus respectively and E. coli JM 109 and Bacillus subtilis UOT0999 as expression hosts. Kulakova et al. [84] prepared genomic library using genomic DNA of Shewanella sp. strain Ac10 in pUC118 and then selected positive clones expressing serine alkaline protease [SapSh]. Positive clones were used for subsequent retrieval of protease ORF from the pUC118 clone and then sub-cloning in pET21a for cloning the SapSh under T7 lac promoter. Recombinant protein was functionally active but shorter in size $(44 \mathrm{kDa})$ than expected $(85 \mathrm{kDa})$ which indicated removal of some protein sequence during protein processing. Sheng et al. [69] also reported cloning of alkaline protease gene from 
psychrophilic Planomicrobium sp. 547 into pTA2 vector. It has been felt since long that a different expression host should be developed for expressing cold-active proteins, since this will assist the proteins is several ways like proper folding and thus retaining activity. Parrilli et al. [111] developed Pseudoalteromonas haloplanktis TAC125 as a versatile psychrophilic host for recombinant protein production by disrupting its gspE gene. Other psychrophilic hosts should be generated so that a diverse array of cold-active proteins along with industrially important protease can be heterologously expressed.

\section{Crystal Structure of Cold-Active Proteases}

X-ray crystallography has revolutionized the study of proteins. So far structure-function relationship of many enzymes has been deduced using this technique. Understanding of tertiary structure of enzymes and spatial arrangement of catalytically important functional groups must be known in order to get information about possible changes in enzyme structure resulting from binding of substrate, products, stabilizers, inhibitors or effector molecules. 3D structure of proteases can provide an insight into the mechanism of the enzymatic action and also provide a template for the design of novel drugs if the studied protease is involved in pathogenesis, e.g., viral ptoreases. Crystallographic studies of proteins can also assist in understanding molecular basis of structure-environment adaptation relationships. Thus proteins in cold environments can be understood in further detail by this technique. Comparative investigations of numerous protein models and crystal structures revealed that cold-adapted enzymes tend to exhibit an attenuation of the strength and number of structural factors known to stabilize protein molecules [112].

Recently Almog et al. [113] reported that the calcium-loaded state is not responsible for the cold adaptation of psychrophilic cold-adapted subtilisin S41 from Antarctic Bacilllus sp. TA41. This conclusion was reached based on comparison of crystal structure of S41 with a mesophilic subtilisin Sph from Bacillus sphaericus 22973. These two subtilisins were highly similar in their calcium binding mode but differed in cold adaptability.

Many cold-active enzymes have been studied so far using crystallographic technique. Some of them include Arthrobacter $\beta$-galactosidase [114], Lipase [115] of Moraxella TA144 a strain from Antarctica, Lipase from Psychrobactor immobilis [116]. Dong et al. [117] solved crystal structure of subtilisin like and psychrophilic protease Apa1 from Antarctic Pseudoalteromonas sp. strain AS11. An aminopeptidase from Aeromonas proteolytica was solved at $1.8 \AA$ by Chevrier et al. [118]. Zhang et al. [119] solved the crystal structure of psychrophilic protease from Flavobacterium YS-80 at $2 \AA$. The marine protease from Flavobacterium acquires a two domain structure. N-terminal domain includes amino acid residues 37-264 and C-terminal comprise of residues from 265 to 480. Zhang et al. (66) compared the structural feature of the marine protease MP of Flavobacterium YS- 80 with another psychrophilic protease PAP from Antarctic Pseudomonas species and mesophilic counterpart AP from Pseudomonas aerugenosa and SMP from S. marcescens (Figure 2). It was found that the $\mathrm{Zn}^{2+}-\mathrm{Tyr}-\mathrm{OH}$ bond in PAP is more flexible in order to facilitate substrate accessibility and to maintain its activity in very low temperatures. Marine protease MP contains seven glycine residues which are not present in AP. Glycine is responsible for flexibility to the protein thus indicating that MP is more flexible in nature than AP [19]. Eight $\mathrm{Ca}^{2+}$ ions and one $\mathrm{Zn}^{2+}$ ions have been positioned in the electron 
density map. The MP has a comparable overall structure to PAP, AP and SMP with as it has a two domain structure as described earlier. After overlapping the overall structure of MP with PAP, AP and SMP using all the $\mathrm{Ca}$ atoms, the main-chain RMSDs were $0.87 \AA$ [with PAP form1], $1.08 \AA$ [with PAP form2], $1.03 \AA$ [with PAP form3], $1.00 \AA$ [with AP] and $1.28 \AA$ [with SMP] [66].

Figure 2. (a) superimposed image of MP [in yellow] with PAP forms 2 [in magenta color] and AP [in cyan] and SMP [in pale green]. Zn and Ca ions shown in figure are from the structure of MP. (b) additional N-terminal $\mathrm{Ca}^{2+}$ binding site is shown in superimposed image of MP [in cornflower blue] with PAP form 1 [in purple] and AP [in cyan] demonstrating a stabilized loop formation shaped in MP. Amino acids of MP which are coordinating to the $\mathrm{Ca}$ ions are depicted as sticks [66].

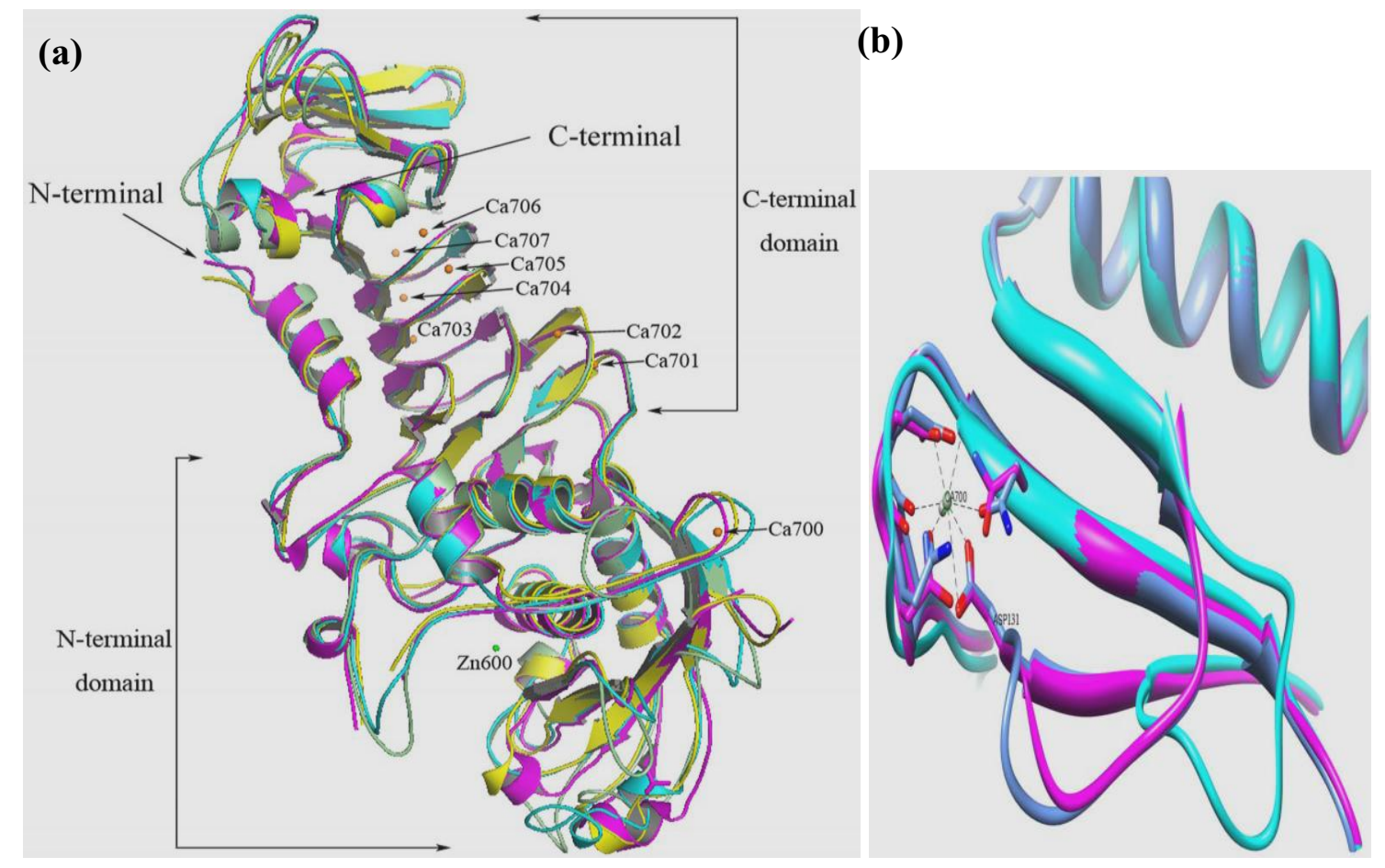

Papaleo et al. [119] studied seven mutant enzyme structures generated by digital effects to know whether substitution of few chosen amino acid residue confer a change in overall shift in optimum temperature or thermal stability of cold-adapted $\alpha$-amylase. The mutation of a few residues alone would not change the thermal behavior of the particular enzyme, and other features also must be addressed to alter the thermal stability of the protein. Such a study can also be carried out for protease also to deduce if thermal stability of the enzyme can be altered. The limited knowledge of the protein structure is quite inadequate to reach the any thumb rule for deciding temperature range of enzymes.

However a general model proposed to explain higher activity at low temperature is that the enzyme possesses a more flexible conformation, metaphorically like an open hand, than their mesophilic and thermophilic counterparts. As a result of this increased flexibility, protein would be thermolabile often observed with cold-active enzymes [120]. In contrast, thermostable enzymes have more rigid and compact conformation more like a fist protecting them against destabilizing forces occurring at higher temperatures. A goal in comparing proteins from extremophiles is to test this and other proposed models for confirming whether such changes result in flexibility. Directed evolution studies have 
recently indicated that there is not a direct correlation between increased activity at low temperature and decreased thermostability [121]. In order to understand structural basis of cold adaptation, more crystal structures of similar mesophilic and thermophilic counterparts, along with the rationalized mutation studies are required. The most frequently reported structural differences between coldadapted psychrozymes and their thermophilic and mesophilic counterparts involve interactions like fewer intra- or inter- subunit salt-bridges, loosely held hydrophobic packing in the protein core, longer surface loops and fewer prolines in such loops, increased number of glycine clusters, reduced number of arginines, improved solvent interactions through additional surface (mostly negative) charges, increased solvent exposure of apolar surface and a better accessibility of the active site [122].

\section{Cold Environment Metagenomics: Tapping Biodiversity}

Geographical regions with low temperature harbor psychrophiles and psychrotolerants. Diverse environments form extremely diverse niches, and the microorganisms are exposed to various extremes like pressure, temperature, nutrient availability and light. These organisms are a treasure of potentially unique biochemical and molecular profiles that might have the enzyme or molecule of enormous biotechnological interest and industrial application. The microbial enzymes from such environments are expected to have quite diverse biochemical and molecular properties. Isolation of both the microbe of interest and the molecule or enzyme of interest from these niches encounters obstacles mainly due to two reasons: first, despite the recent advances in the development of new culturing methodologies, most extremophiles could not be cultured using available technologies, and second, the problem of very low amount of biomass and thus the yield of DNA is very low for molecular analysis. Environmental genomics provides an answer for exploitation of the wealth offered by nature in extreme environments. Basic steps in this approach involve sample collection from the niche of interest such as cold environment and then this sample is processed for isolation of total environmental DNA. This environmental DNA is used either for cloning into suitable vector for genomic library construction or directly for sequencing or amplification using universal primers. These libraries are screened for the presence of enzymes of interest or for biomolecules of interest. The use of high throughput screening techniques and robotic systems make the screening process much faster and useful as large number of clones and libraries can be screened in relatively shorter time.

Environmental genomics approach has been used for isolating many cold-adapted enzymes like lipases [123,124], cellulases [125], amylases [126], xylanases [127] from the microflora existing in the cold environments. The isolation and characterization of various novel cold-adapted enzymes highlights and supports the potential of the cold environment metagenomics in future for the discovery of psychrophilic proteases too. Berlemont et al. [128] isolated three proteases along with other commercially important enzymes from Antarctic soil metagenome. This approach will accelerate the biotechnological exploitation of microbial diversity present in cold environments.

\section{Enhancing Thermo-Stability of Cold-Active Proteases}

The cold-active proteases from different microorganisms vary in their thermostability and alkalistability $[41,43,73,65,63,101,105,129-131]$. High proteolytic activity at lower temperatures shown by cold-active proteases is important in the commercial usage of proteases, but their low 
thermal stability is a common drawback that hinders their use in industries. To overcome this problem, various strategies have been used, among which reinforcement of the overall rigidity of the enzyme structure by increasing the number of disulfide bridges, intra-molecular salt bridges and shortening the length of loop regions are most commonly used [132,133]. Several ideas have been put forward for explaining the thermostability of proteins. In addition to providing insight into structural modifications, protein fluctuations can provide a mechanism of thermal stability too [134]. Experimental techniques such as nuclear magnetic resonance (NMR) [135,136], neutron diffraction methods [137] and theoretical approaches based on computer simulations on protein dynamics in solution [138,139] have supported the proposed idea. Molecular dynamics simulation has also been used to provide detailed atomic models of the protein stability and dynamics [140,141]. Attempts have been made to tailor the psychrophilic enzymes to have properties of industrial interest such as increased thermostability, tolerance to bleaches and detergents and to different organic solvents so that the proteins can become process friendly. The protein engineering has been used to alter the properties of the proteins by making changes in their primary structures. Mainly two engineering techniques have been used in attempts to create thermostable proteases: one is random mutagenesis and second is sitedirected mutagenesis [SDM]. Pantoliano et al. [142] reported the improved thermostability and extreme alkalinity of subtilisin BPN by substitution of six individual amino acids [N218S, G169A, Y217K, M50F, Q206C, N76D]. The inactivation rate decreased several times as compared to the wild type BPN subtilisin. Strausberg et al. [143] reported 1000 times increase in $\mathrm{t}_{1 / 2}$ of subtilisin BPN of $B$. subtilis by loop removal, cassette mutagenesis and screening procedure. Shao et al. [144] reported 8 -fold increase in $\mathrm{t}_{1 / 2}$ of subtilisin $\mathrm{E}$ by random priming and screening methods.

A mutant subtilisin $\mathrm{E}$ with enhanced thermostability at $60^{\circ} \mathrm{C}$ was generated using SDM [145]. The thermostability and activity of subtilisin-like serine proteinase [VPR] had been improved by SDM approach [146]. Such studies clearly indicate that it is possible to improve one character [activity/stability] without affecting the other. Narinx et al. [147] performed SDM for introduction of an additional salt bridge, disulfide bonds, and increasing the affinity of the enzyme for calcium, and found that stability of the molecular structure was achieved by a modification of a calcium ligand T85D. The mutated enzyme was thermostable like mesophilic subtilisin.

Directed evolution of proteins involves recombinant DNA techniques such as DNA shuffling, random priming recombination and the staggered extension process [StEP]. Zhao and Arnold [148] reported increase in thermostability of subtilisin $\mathrm{E}$ by converting it to thermitase using directed evolution.

While studying the effect of trimethylamine N-oxide (TMAO) on the structure, activity, and stability of a psychrophilic protease (deseasin MCP-01), He et al. [149] suggested the possibility of using TMAO as an effective stabilizer to enhance the thermostability of a cold-adapted enzyme without compromising with its psychrophilic characters such as its overall structural flexibility and high catalytic efficiency at low temperature. The isolation temperature plays an important role in determining the cold adaptability of the enzyme of interest, as isolation temperatures is found to affect the enzyme properties. Vazquez and Mac Cormack [150] reported that the lower the strain isolation temperatures better the cold-adapted proteases in terms of optimal temperature and activation energy. Thus by using the recombineering and classical methods, thermostability of cold-active proteases can be improved. 


\section{Applications of Cold-Active Proteases}

Economic benefits can be achieved by using cold-active proteases as they allow working at low temperatures even in an industrial scale. For example instead of heating and bringing the temperature during the industrial peeling process of leather by conventional protease from mesophilic or thermophilic microbes, the process can be performed at the temperature of tap water by using cold-active proteases. With the use of cold-active protease, energy saving is possible.

Proteases as a group found application in various fields such as baking, brewing, cheese making, in preparation of protein concentrates, leather industry, silk degumming, detergent industry, pharmaceutical industry, bioremediation, silver recovery from X-ray film and photographic industry are few to name the areas. The cold-active proteases find application in household processes, where they can be used for removal of macromolecular stains from fabrics along with other detergent components. As the whole process would be done at low temperature, the colors of the clothes will remain protected exposure to higher temperature. The treatment of wool and silk by protease can bring new and unique finishing to the surface of wool and silk fibers. Nowadays in textile industry, the synthetic fiber is being used. Some of the synthetic fibers cannot tolerate temperatures above 50-60 ${ }^{\circ} \mathrm{C}$, and hence, require varied washing procedures [151]. During the past few years, a trend of lower washing temperature has gained popularity. Cold-active protease from B. subtilis showed stability in the presence of SDS and exhibited enhanced activity in Tween 80 and Wheel detergent, $\mathrm{pH}$ and detergent compatibility at low temperature, and thus, suits application in detergent formulation [35]. Protease from Bacillus sp.158 has found application in contact lens cleaning, thus increasing the transmittance of the lenses [152]. The protease of P. aeruginosa MCM B-327 was found to be useful in dehairing hides (Figure 3) [99].

Figure 3. Buffalo hide dehairing by PA02 protease of $P$. aeruginosa MCM B-327. (a) chemical treatment, (b) crude enzyme treatment, (c) control-water treatment [99].

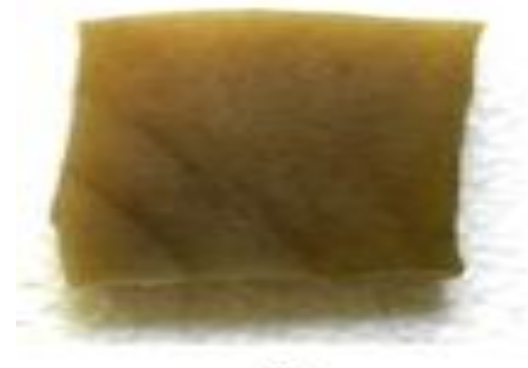

A

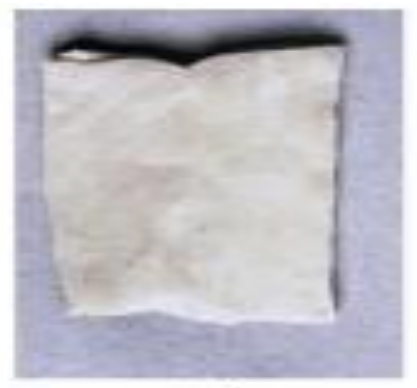

$\mathbf{B}$

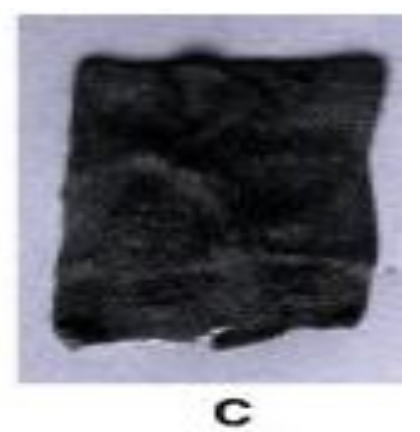

In the food industry, the property of having high catalytic activity at low-temperature allows transformation of heat labile products. They can be used in processes such as fermentation of fish or soy sauce with no spoilage and alterations in flavor and nutritional value. Cold-active proteases along with lipases can be used as rennet substitutes to accelerate the ripening of slow-ripening cheeses. Additionally cold-active proteases can find utility in softening and taste development of frozen or refrigerated meat products. Apart from this, thermal lability of such proteases can result in rapid inactivation by mild heat treatment [30]. This feature will prove beneficial in preserving the quality in the food industry. 
Cold-adapted or low temperature tolerant enzymes suit well in waste management in cold environments, where the degradation capabilities of endogenous microflora are reduced due to low temperatures. Cold-adapted proteases thus can be used to optimize present day industrial processes and for developing future technologies with less energy inputs and process cost by removing the cost of heat inactivation step [28,30].

\section{Conclusions and Future Perspectives}

A wide range of microorganisms from diverse habitats, permanently cold as well as those exposed to cold during a part of the year, are known to produce cold-active proteases. Metagenomic culture-independent approaches have also been initiated for obtaining novel cold-active biocatalysts including proteases. A few attempts have been made to engineer and manipulate the cold-active proteases, but much success has not yet been achieved. Cloning of genes encoding cold-active protease from the wild strains and their over expression in suitable hosts is another area of research for cost effective production of these enzymes. The field of cold-active protease research is still wide open and expected to achieve spectacular success in the nearest future.

\section{Acknowledgements}

One of us (SJ) is grateful to the Council of Scientific \& Industrial Research, Govt. of India, New Delhi for the award of fellowship while writing this review.

\section{References}

1. D’Amico, S.; Collins, T.; Marx, J.; Feller, G.; Gerday, C. Psychrophilic microorganisms: challenges for life. EMBO Rep. 2006, 7, 385-389.

2. Gomes, J.; Steiner, W. The biocatalytic potential of extremophiles and extremozymes. Food Technol. Biotechnol. 2004, 42, 223-235.

3. Rodrigues, D.F.; Tiedje, J.M. Coping with our cold planet. Appl. Environ. Microbiol. 2008, 74, 1677-1686.

4. Margesin, R.; Schinner, F.; Marx, J.C.; Gerday, C. Psychrophiles: from Biodiversity to Biotechnology; Springer: Berlin, Heidelberg, 2008; pp. 211-224.

5. Gounot, A. Bacterial life at low temperature: physiological aspects and biotechnological implications. J. Appl. Bacteriol. 1991, 71, 386-397.

6. Huston, A.L.; Krieger-Brockett, B.B.; Deming, J.W. Remarkably low temperature optima for extracellular enzyme activity from Arctic bacteria and sea ice. Environ. Microbiol. 2000, 2, 383388.

7. Feller, G.; Bussy, O.L.; Gerday, C. Expression of psychrophilic genes in mesophilic hosts: assessment of the folding state of a recombinant $\alpha$-amylase. Appl. Environ. Microbiol. 1998, 64, $1163-1165$.

8. Aghajari, N.; Feller, G.; Gerday, C.; Haser, R. Crystallization and preliminary X-ray diffraction studies of $\alpha$-amylase from the Antarctic psychrophile Alteromonas haloplanctis A23. Prot. Sci. 1996, 5, 2128-2129. 
9. Jeon, J.H.; Kim, J.T.; Kim, Y.J.; Kim, H.K.; Lee, H.S.; Kang, S.G.; Kim, S.J.; Lee, J.H. Cloning and characterization of a new cold-active lipase from a deep-sea sediment metagenome. Appl. Microbiol. Biotechnol. 2009, 81, 865-874.

10. Suzuki, T.; Nakayama, T.; Kurihara, T.; Nishino, T.; Esaki, N. Cold-active lipolytic activity of psychrotrophic Acinetobacter sp. strain no. 6. J. Biosci. Bioeng. 2001, 92, 144-148.

11. Feller, G.; Amico, D.S.; Benotmane, A.M.; Joly, F.; Van Beeumen, J.; Gerday, C. Purification, characterization of nucleotide sequence of the thermolabile $\alpha$-amylase from Antarctic psychrotroph Alteromonas haloplanktis A23. J. Biol. Chem. 1992, 267, 5217-5221.

12. Villeret, V.; Chessa, J.P.; Gerday, C.; Van Beeumen, J. Preliminary crystal structure determination of the alkaline protease from Antarctic psychrophile Pseudomonas aeruginosa. Prot. Sci. 1997, 6, 2462-2464.

13. Gerike, U.; Danson, M.J.; Hough, D.W. Sequencing and expression of the gene encoding a coldactive citrate synthase from an antarctic bacterium strain DS2-3R. Eur. J. Biochem. 1997, 248, 49-57.

14. Feller, G.; Gerday, C. Psychrophilic enzymes: molecular basis of cold adaptation. Cell. Mol. Life Sci. 1997, 53, 830-841.

15. Kim, S.Y.; Hwang, K.Y.; Kim, S.H.; Sung, H.C.; Han, Y.S.; Cho, Y. Structural basis of cold adaptation. Sequence, biochemical properties and crystal structure of malate dehydrogenase from a psychrophilic Aquaspirillum articum. J. Biol. Chem. 1999, 274, 11761-11767.

16. Alvarez, M.; Johan, P.H.; Zeelen, J.P.; Veronique Mainfroid, V.; Joseph, A.; Martial, J.A. Triose phosphate isomerase (TIM) of the psychrophilic bacterium Vibrio marinus. J. Biol. Chem. 1998, 273, 2199-2206.

17. Georlette, D.; Blaise, V.; Collins, T.; D'Amico, S. Some like it cold: biocatalysis at low temperatures. FEMS Microbiol. Rev. 2004, 28, 25-42.

18. Collins, T.; Meuwis, M.A.; Stals, I.; Claeyssens, M.; Feller, G.; Gerday, C. A novel family 8 xylanase, functional and physicochemical characterization. J. Biol. Chem. 2002, 277, 3513335139.

19. Russell, R.J.; Gericke, U.; Danson, M.J.; Hough, D.W.; Taylor, G.L. Structural adaptations of the cold-active citrate synthase from an Antarctic bacterium. Structure (Lond) 1998, 6, 351-361.

20. Birgisson, H.; Delgado, O.; Arroyo, L.G.; Hatti-Kaul, R.; Mattiasson, B. Cold-adapted yeasts as producers of cold-active polygalacturonases. Extremophiles 2003, 7, 185-193.

21. Akila, G.; Chandra, T.S. A novel cold-tolerant Clostridium strain PXYL1 isolated from a psychrophilic cattle manure digester that secretes thermolabile xylanase and cellulose. FEMS Microbiol. Lett. 2003, 219, 63-67.

22. Mavromatis, K.; Lorito, M.; Woo, S.L.; Bouriotis, V. Mode of action and antifungal properties of two cold-adapted chitinases. Extremophiles 2003, 7, 385-390.

23. Sakamoto, T.; Ihara, H.; Kozakic, S.; Kawasaki, H. A cold-adapted endo-arabinanase from Penicillium chrysogenum. Biochim. Biophys. Acta 2003, 1624, 70-75.

24. Nakagawa, T.; Nagaoka, T.; Taniguchi, S.; Miyaji, T.; Tomizuka, N. Isolation and characterization of psychrophilic yeasts producing cold-adapted pectinolytic enzymes. Lett. Appl. Microbiol. 2004, 38, 383-387. 
25. Rao, M.B.; Tanksale, A.M.; Ghatge, M.S.; Deshpande, V.V. Molecular and biotechnological aspects of microbial proteases. Microbiol. Mol. Biol. Rev. 1998, 62, 597-635.

26. Godfrey, T.; West, S. Introduction to industrial enzymology. In Industrial Enzymology, 2nd ed.; Godfrey, W., Ed.; Macmillan Press: London, UK, 1996; pp. 1-8.

27. Gaur, S.; Agrahari, S.; Wadhwa, N. Purification of Protease from Pseudomonas thermaerum GW1 Isolated from poultry waste site. Open Microbiol. J. 2010, 4, 67-74.

28. Cavicchioli, R.; Siddiqui, K.S.; Andrews, D.; Sowers, K.R. Low-temperature extremophiles and their applications. Curr. Opin. Biotechnol. 2002, 13, 253-161.

29. Deming, J.W. Psychrophiles and polar regions. Curr. Opin. Biotechnol. 2002, 5, 301-309.

30. Margesin, R.; Feller, G.; Gerday, C.; Russell, N. Cold-adapted microorganisms: adaptation strategies and biotechnological potential. In The Encyclopedia of Environmental Microbiology, Bitton Eds.; Wiley: New York, 2002; pp. 871-885.

31. Gerday, C.; Aittaleb, M.; Bentahir, M.; Chessa, J.P.; Claverie, P.; Collins. T.; D’Amico, S.; Dumont, J.; Garsoux, G.; Georiette, D.; Hoyoux, A.; Lonhience, T.; Meuwis, M.A;. Feller, G. Cold-adapted enzymes, from fundamentals to biotechnology. Trends Biotechnol. 2000, 18, 103107.

32. Morita, R.J. Psychrophilic bacteria. Bacteriol. Rev. 1975, 39, 144-167.

33. Feller, G. Molecular adaptations to cold in psychrophilic enzymes. Cell. Mol. Life Sci. 2003, 60, $648-662$.

34. Oh, K.H.; Seong, C.S.; Lee, S.W.; Kwon, O.S.; Park, Y.S. Isolation of a psychrotrophic Azospirillum sp. and characterization of its extracellular protease. FEMS Microbiol. Lett.1999, 174, 173-178.

35. Baghel, V.S.; Tripathi, R.D.; Ramteke, R.W.; Gopal, K.; Dwivedi, S.; Jain, R.K.; Rai, U.N.; Singh, S.N. Psychrotrophic proteolytic bacteria from cold environments of Gangotri glacier, Westren Himalaya India. Enzyme Microbial. Technol. 2005, 36, 654-659.

36. Alam, S.I.; Dube, S.; Reddy, G.S.N.; Bhattacharya, B.K.; Shivaji, S.; Singh, L. Purification and characterization of extracellular protease produced by Clostridium sp. from Schirmacher oasis, Antarctica. Enzyme Microbial. Technol. 2005, 36, 824-831.

37. Wang, Q.; Hou, Y.; Xu, Z.; Miao, J.; Li, G. Optimization of cold-active protease production by the psychrophilic bacterium Colwellia sp NJ341 with response surface methodology. Biores. Technol. 2008, 99, 1926-1931.

38. Olivera, N.L.; Sequeiros, C.; Nievas, M.L. Diversity and enzyme properties of proteaseproducing bacteria isolated from sub- Antarctic sediments of Isla de Los Estados, Argentina. Extremophiles 2007, 11, 517-526.

39. Kuddus, M.; Ramteke, P.W. A cold-active extracellular metalloprotease from Curtobacterium luteum. (MTCC 7529), enzyme production and characterization. J. Gen. Appl. Microbiol. 2008, 54, 385-392.

40. Kasana, R.C.; Yadav, S.K. Isolation of a psychrotrophic Exiguobacterium sp SKPB5 (MTCC 7803) and characterization of its alkaline protease. Curr. Microbiol. 2007, 54, 224-229.

41. Margesin, R.; Dieplinger, H.; Hofmann, J.; Sarg, B.; Lindner, H. A cold-active extracellular metalloprotease from Pedobacter cryoconitis-production and properties. Res. Microbiol. 2005, $156,499-505$. 
42. Zhu, H.Y.; Tian, Y.; Hou, Y.H.; Wang, T.H. Purification and characterization of the cold-active alkaline protease from marine cold-adaptive Penicillium chrysogenum FS010. Mol. Biol. Rep. 2009, 36, 2169-2174.

43. Zeng, R.; Zhang, R.; Zhao, J.; Lin, N. Cold-active serine alkaline protease from the psychrophilic bacterium Pseudomonas strain DY-A: enzyme purification and characterization. Extremophiles 2003, 7, 335-337.

44. Denner, E.B.; Mark, B.; Busse, H.J.; Turkiewicz, M.; Lubitz, W. Psychrobacter proteolyticus sp. Nov., a psychrotrophic, halotolerant bacterium isolated from the Antarctic krill Euphausia superba Dana, excreting a cold-adapted metalloprotease. Syst. Appl. Microbiol. 2001, 24, 44-53.

45. Larsen, A.L.; Moe, E.; Helland, R.; Gjellesvik, D.R.; Willassen, N.P. Characterization of a recombinantly expressed proteinase K-like enzyme from a psychrotrophic Serratia sp. FEBS J. 2006, 273, 47-60.

46. Kristjansson, M.M.; Magnusson, O.T.; Gudmundsson, H.M.; Alfredsson, G.A.; Matsuzawa, H. Properties of a subtilisin-like proteinase from a psychrotrophic Vibrio species comparison with proteinase K and aqualysin I. Eur. J. Biochem. 1999, 260, 752-760.

47. Margesin, R.; Schinner, F. Characterization of a metalloprotease from psychrophilic Xanthomonas maltophilia. FEMS Microbiol. Lett. 1991, 79, 257-262.

48. Yu, Y.; Li, H.R.; Zeng, Y.X.; Chen, B. Bacterial diversity and bioprospecting for cold-active hydrolytic enzymes from culturable bacteria associated with sediment from Nella Fjord, Eastern Antarctica. Mar. Drugs 2011, 9, 184-195.

49. Kuddus, M.; Ramteke, P.W. Production optimization of an extracellular cold-active alkaline protease from Stenotrophomonas maltophilia MTCC 7528 and its application in detergent industry. Afr. J. Microbiol. Res. 2011, 7, 809-816.

50. Thangam, E.B.; Rajkumar, G.S. Studies on the production of extracellular protease by Alcaligenes faecalis. World J. Microb. Biot. 2000, 16, 663-666.

51. Kobayashi, T.; Lu, J.; Li, Z.; Hung, V.S.; Kurata, A.; Hatada, Y.; Takai, K.; Ito, S.; Horikoshi, K. Extremely high alkaline protease from a deep-subsurface bacterium, Alkaliphilus transvaalensis. Appl. Microbiol. Biotechnol. 2007, 75, 71-80.

52. Suzuki, S.; Odagami, T. Low-temperature-active thiol protease from marine bacterium Alteromonas haloplanktis. J.Biotechnol.1997, 15, 230-233.

53. Damare, C.; Raghukuma, C.; Muraleedharan, U.D.; Raghukumar, S. Deep-sea fungi as a source of alkaline and cold-tolerant proteases. Enzyme Microb. Tech. 2006, 39, 172-181.

54. Kaur, S.; Vohra, R.M.; Kapoor, M.; Beg, Q.K.; Hoondal, G.S. Enhanced production and characterization of a highly thermostable alkaline protease from Bacillus sp. P-2. World J. Microb. Biot. 2001, 17, 125-129.

55. Okuda, M.; Sumitomo, N.; Takimura, Y.; Ogawa, A.; Saeki, K.; Kawai, S.; Kobayashi, T.; Ito, S. A new subtilisin family: nucleotide and deduced amino acid sequences of new high-molecularmass alkaline proteases from Bacillus spp. Extremophiles 2008, 4, 229-235.

56. Son, E.S.; Kim, J.I. Multicatalytic alkaline serine protease from the psychrotrophic Bacillus amyloliquefaciens S94. J. Microbiol. 2003, 41, 58-62. 
57. Joshi, G.K.; Kumar, S.; Sharma, V. Production of moderately halotolerant, SDS stable alkaline protease from Bacillus cereus MTCC 6840 isolated from lake Nainital, Uttaranchal state, India. Braz. J. Microbiol. 2007, 38, 773-779.

58. Toyokawa, Y.; Takahara, H.; Reungsang, A.; Fukuta, M.; Hachimine, Y.; Tachibana, S.; Yasuda, M. Purification and characterization of a halotolerant serine proteinase from thermotolerant Bacillus licheniformis RKK-04 isolated from Thai fish sauce. Appl. Microbiol. Biotechnol. 2010, 86, 1867-1875.

59. Kumar, C.G. Purification and characterization of a thermostable alkaline protease from alkalophilic Bacillus pumilus. Lett. Appl. Microbiol. 2002, 34, 13-17.

60. Rao, Y.K.; Lu, S.C.; Liu, B.L.; Tzeng, Y.M. Enhanced production of an extracellular protease from Beauveria bassiana by optimization of cultivation processes. Biochem. Eng. J. 2006, 28, 57-66.

61. Ray, M.K.; Devi, K.U.; Kumar, G.S.; Shivaji, S. Extracellular protease from the Antarctic yeast Candida humicola. Appl. Environ. Microbiol.1992, 58, 1918-1923.

62. Wang, Q.; Miao, J.L.; Hou, Y.H.; Ding, Y.; Wang, G.D.; Li, G.Y. Purification and characterization of an extracellular cold-active serine protease from the psychrophilic bacterium Colwellia sp. NJ341. Biotech. Lett. 2005, 27, 1195-1198.

63. Huston, A.L.; Methe, B.; Deming, J.W. Purification, characterization, sequencing of an extracellular cold-active aminopeptidase produced by marine psychrophile Colwellia psychrerythraea strain 34H. Appl. Environ. Microbiol.2004, 70, 2321-2328.

64. Chellappan, S.; Jasmin, C.; Basheer, S.M.; Elyas, K.K.; Bhat, S.G.; Chandrasekaran, M. Production, purification and partial characterization of a novel protease from marine Engyodontium album BTMFS10 under solid state fermentation. Process Biochem.2006, 41, 956961.

65. Nakajima, M.; Mizusawa, K.; Yoshida, F. Purification and properties of an extracellular proteinase of psychrophilic Escherichia freundii. Eur. J. Biochem. 1974, 44, 87-96.

66. Zhang, S.C.; Sun, M.; Li, T.; Wang, Q.H.; Hao, J.H. Structure analysis of a new psychrophilic marine protease. PLoS One 2011, doi:10.1371/ journal.pone.0026939.

67. Morita, Y.; Hasan, Q.; Sakaguchi, T.; Murakami, Y.; Yokoyama, K.; Tamiya, E. Properties of a cold-active protease from psychrotrophic Flavobacterium balustinum P104. Appl. Microbiol. Biotechnol. 1998, 50, 669-675.

68. Turkiewicz, M.; Pazgier, M.; Kalinowska, H.; Bielecki, S. A cold adapted extracellular serine protease of the yeast. Leucosporidium antarcticum. Extremophiles 2003, 7, 435-442.

69. Sheng, Y.X.; Lin, C.X.; Zhong, X.U.X.; Ying, Z.R. Cold-adaptive alkaline protease from the psychrophilic Planomicrobium sp. 547: Enzyme characterization and gene cloning. Adv. Polar Sci. 2011, 22, 49-54.

70. Xiong, H.; Song, S.; Xu, Y.; Tsoi, M.Y.; Dobretsov, S.; Qian, P.Y. Characterization of proteolytic bacteria from the Aleutian deep-sea and their proteases. J. Ind. Microbiol. Biot.2007, $34,63-71$.

71. Vazquez, S.C.; Hernández, E.; Mac Cormack, W.P. Extracellular proteases from the Antarctic marine Pseudoalteromonas sp. P96-47 strain. Rev. Argent. Microbiol. 2008, 40, 63-71. 
72. Chen, X.L.; Xie, B.B.; Lu, J.T.; He, H.L.; Zhang, Y. A novel type of subtilase from the psychrotolerant bacterium Pseudoalteromonas sp. SM9913: Catalytic and structural properties of deseasin MCP-01. Microbiology 2007, 153, 2116-2125.

73. Vazquez, S.C.; Coria, S.H.; Mac Cormack, W.P. Extracellular proteases from eight psychrotolerant Antarctic strains. Microbiol. Res. 2004, 159, 157-166.

74. Chessa, J.P.; Petrescu, I.; Bentahir, M.; Beeumen, J.V.; Gerday, C. Purification, physicochemical characterization and sequence of a heat labile alkaline metalloprotease isolated from a psychrophilic Pseudomonas species. Biochim. Biophys. Acta (BBA) - Protein Structure and Molecular Enzymology 2000, 1-2, 265-274.

75. Patil, U.; Chaudhari, A. Optimal production of alkaline protease from solvent- tolerant alkaliphilic Pseudomonas aeruginosa MTCC 7926. Indian J. Biotechnol. 2011, 10, 329-339.

76. Yang, C.; Yang, F.; Hao, J.; Zhang, K.; Yuan, N.; Sun, M. Identification of a proteolytic bacterium HW08 and characterization of its extracllular cold-Active alkaline metalloprotease ps5. Biosci. Biotechnol. Biochem. 2010, 74, 1220-1225.

77. Koka, R.; Weimer, B.C. Isolation and characterization of a protease from Pseudomonas fluorescens RO98. J. Appl. Microbiol.2000, 89, 280-288.

78. Hamamato, T.; Kaneda, M.; Horikoshi, K.; Kudo, T. Characterization of a Protease from a psychrotroph, Pseudomonas fluorescens 114. Appl. Environ. Microbiol. 1994, 60, 3878-3880.

79. Meza, J.C.; Auria, R.; Lomascolo, A.; Sigoillot, J.C.; Casalot, L. Role of ethanol on growth, laccase production and protease activity in Pycnoporus cinnabarinus ss3. Enzyme Microb. Tech. 2007, 41,162-168.

80. Shanmughapriya, S.; Krishnaveni, J.; Selvin, J.; Gandhimathi, R.; Arunkumar, M.; Thangavelu, T.; Kiran, G.S.; Natarajaseenivasan, K. Optimization of extracellular thermotolerant alkaline protease produced by marine Roseobacter sp. (MMD040). Bioprocess Biosyst. Eng. 2008, 31, 427-433.

81. Tariq, A.L.; Reyaz, A.L.; Prabakaran, J.J. Purification and characterization of $56 \mathrm{kDa}$ cold-active protease from Serratia marcescens. Afr. J. Microbiol. Res. 2011, 5, 5841-5847.

82. Morita, Y.; Kondoha, K.; Hasanb, Q.; Sakaguchia, T.; Murakamia, Y.; Yokoyamaa, K.; Tamiyaa, E. Purification and characterization of a cold-Active protease from psychrotrophic Serratia marcescens AP3801. J. Am. Oil Chem. Soc. 1997, 11, 1377-1383.

83. Mozhina, N.V.; Burmistrova, O.A.; Pupov, D.V.; Rudenskaya, G.N.; Dunaevsky, Y.E.; Demiduk, I.V.; Kostrov, S.V. Isolation and properties of Serratia proteamaculans 94 cysteine protease. Russ. J. Bioorg. Chem. 2008, 34, 274-279.

84. Kulakova, L.; Galkin, A.; Kurihara, T.; Yoshimura, T.; Esaki, N. Coldactive serine alkaline protease from the psychrotrophic bacterium Shewanella strain ac10, gene cloning and enzyme purification and characterization. Appl. Environ. Microbiol. 1999, 65, 611-617.

85. Saba, I.; Qazi, P.H.; Rather, S.A.; Dar, R.A.; Qadri, Q.A.; Ahmad, N.; Johri, S.; Taneja, S.S.S. Purification and characterization of a cold-active alkaline protease from Stenotrophomonas sp., isolated from Kashmir, India. World J. Microbiol. Biotechnol. 2012, 28, 1071-1079.

86. Tokiwa, Y.; Kitagawa, M.; Fan, H.; Raku, T.; Hiraguri, Y.; Shibatani, S.; Kurane, R. Synthesis of vinyl arabinose ester catalyzed by protease from Streptomyces sp. Biotechnol. Tech. 1999, 13, 173-176. 
87. Lopes, A.; Coelho, R.R.R.; Meirelles, M.N.L.; Branquinha, M.H.; Vermelho, A.B. Extracellular serine proteinase isolated from Streptomyces alboniger: Partial characterization and effect of aprotinin on cellular structure. Mem. Inst. Oswaldo Cruz. 1999, 94, 763-770.

88. Elibol, M.; Moreira, A.R. Optimizing some factors affecting alkaline protease production by a marine bacterium Teredinobacter turnirae under solid state fermentation. Process Biochem. 2005, 40, 1951-1956.

89. Kredics, L.; Terecskei, K.; Antal, Z.; Szekeres, A.; Hatvani, L.; Manczinger, L.; Vagvolgyi, C. Purification and preliminary characterization of a cold-adapted extracellular proteinase from Trichoderma atroviride. Acta Biol. Hung. 2008, 59, 259-268.

90. Hamamato, T.; Kaneda, M.; Kudo, T.; Horikoshi, K. Characterization of a protease from a psychrophilic Vibrio sp Strain 5709. J. Mar. Biotechnol. 1995, 2, 219-222.

91. Ward, O.P. Proteolytic Enzymes. In: Comprehensive Biotechnology; Moo-Young Ed.; Pergamon Press: Oxford, UK, 1985; Volume 3, pp. 789-818.

92. Morihara, K. Comparative specificity of microbial proteinases. Adv. Enzymol. 1974, 41, 179243.

93. Hartley, B.S. Proteolytic enzymes. Annu. Rev. Biochem.1960, 29, 45-72.

94. Joo, H.S.; Kumar, C.G.; Park, G.C.; Paik, S.R.; Chang, C.S. Oxidant and SDS-stable alkaline protease from Bacillus clausii I-52, production and some properties. J. Appl. Microbiol. 2003, 95, 267-272.

95. Vazquez, S.C.; MacCormack, W.P.; Rios Merino, L.N.; Fraile, E.R. Factors influencing protease production by two Antarctic strains of Stenotrophomonas maltophilia. Rev. Argent. Microbiol. 2000, 32, 53-62.

96. Dube, S.; Singh, L.; Alam, S.I. Proteolytic anaerobic bacteria from lake sediment of Antarctica. Enzyme Microb. Tech. 2001, 20, 114-118.

97. Saeki, K.; Iwata, J.; Watanabe, Y.; Tamai, Y. Purification and characterization of an alkaline protease from Oerskovia xanthineolytica TK-1. J. Ferment. Bioeng. 1994, 77, 554-556.

98. Khairullin, R.F.; Mikhailova, A.G.; Sebyakina, T.Y.; Lubenets, N.L.; Ziganshin, R.H.; Demidyuk, I.V.; Gromova, T.Y.; Kostrov, S.V.; Rumsh, L.D. Oligopeptidase B from Serratia proteamaculans. I. Determination of primary structure, isolation, and purification of wild-type and recombinant enzyme variants. Biochem. (Moscow) 2009, 74, 1164-1172.

99. Zambare, V.; Nilegaonkar, S.; Kanekar, P. A novel extracellular protease from Pseudomonas aeruginosa MCM B-327: Enzyme production and its partial characterization. New Biotechnol. 2011, 28, 173-181.

100. Mikhailova, A.G.; Likhareva, V.V.; Khairullin, R.F.; Lubenets, N.L.; Rumsh, L.D.; Demidyuk, I.V.; Kostrov, S.V. Psychrophilic trypsin-type protease from Serratia proteamaculans. Biochem. (Moscow) 2006, 71, 563-570.

101. Vazquez, S.; Ruberto, L.; Cormack, W.M. Properties of extracellular proteases from three psychrotolerant Stenotrophomonas maltophilia isolated from Antarctic soil. Polar Biol. 2005, 28, 319-325.

102. Irwin, J.A.; Alfredesson, G.A.; Lanzetti, A.J.; Haflidi, M.; Gudmundsson, H.M.; Engel, P.C. Purification and characterization of a serine peptidase from the marine psychrophile strain PA43. FEMS Microbiol. Lett. 2001, 201, 285-290. 
103. Feller, G.; Narinx, E.; Arpingy, J.L.; Aittaleb, M.; Baise, E.; Genicot, S.; Gerday, C. Enzymes from psychrophilic organisms. FEMS Microbiol. Rev. 1996, 18, 189-202.

104. Feller, G.; Payan, F.; Theys, F.; Qian, M.; Haser. R.; Gerday, C. Stability and structural analysis of $\alpha$-amylase from the Antarctic psychrophile Alteromonas haloplanctis A23. Eur. J. Biochem. 1994, 222, 441-447.

105. Yan, B.Q.; Chen, X.L.; Hou, X.Y.; He, H.L.; Zhou, B.C.; Zhang, Y.Z. Molecular analysis of the gene encoding a cold-adapted halophilic subtilase from deep-sea psychrotolerant bacterium Pseudoalteromonas sp. SM9913: cloning, expression, characterization and function analysis of the C-terminal PPC domains. Extremophiles 2009, 13, 725-733.

106. Patel, T.R.; Jackman, D.M.; Bartlett, F.M. Heat-Stable protease from Pseudomonas fluorescens T16, purification by affinity column chromatography and characterization. Appl. Environ. Microbiol. 1983. 46, 333-337.

107. Kim, J.; Lee, S.M.; Jung, H.J. Characterization of calcium-activated bifunctional peptidase of the psychrotrophic Bacillus cereus. J. Microbiol. 2005, 43, 237-243.

108. Ni, X.; Yue, L.; Chi, Z.; Li, J.; Wang, X.; Madzak, C. Alkaline protease gene cloning from the marine yeast Aureobasidium pullulans HN2-3 and the protease surface display on Yarrowia lipolytica for bioactive peptide production. J. Mar. Biotechnol. 2009, 11, 81-89.

109. Wintrode, P.L.; Miyazaki, K.; Arnold, F.H. Cold adaptation of a mesophilic subtilisin-like protease by laboratory evolution. J. Biochem. 2000, 275, 31635-31640.

110. Taguchi, S.; Ozaki, A.; Momose, H. Engineering of a Cold-adapted protease by sequential random mutagenesis and a screening system. Appl. Environ. Microbiol. 1998, 64, 492-495.

111. Parrilli, E.; Vizio, D.D.; Cirulli, C.; Tutino, M.L. Development of an improved Pseudoalteromonas haloplanktis TAC125 strain for recombinant protein secretion at low temperature. Microb. Cell Fact. 2008, doi:10.1186/1475-2859-7-2.

112. Huston, A.L. Psychrophiles: From Biodiversity to Biotechnology; Springer: Heidelberg, Germany, 2008; pp. 347-363.

113. Almog, O.; González, A.; Godin, N.; de Leeuw, M.; Mekel, M.J.; Klein, D.; Braun, S. The crystal structures of the psychrophilic subtilisin S41 and the mesophilic subtilisin Sph reveal the same calcium-loaded state. Proteins 2009, 74, 489-496.

114. Trimbur, D.E.; Gutshall, K.R.; Prema, P.; Brenchley, J.E. Characterization of a psychrotrophic Arthrobacter gene and its cold-active beta galactosidase. Appl. Environ. Microbiol. 1994, 60, 4544-4552.

115. Feller, G.; Thiry, M.; Gerday, C. Nucleotide sequence of the lipase gene lip2 from the Antarctic psychrotroph Moraxella TA 144 and site-specific mutagenesis of the conserved serine and histidine residues. DNA Cell Biol. 1991, 10, 381-388.

116. Arpigny, J.L.; Feller, G.; Gerday, C. Cloning, sequence and structural features of a lipase from the Antarctic facultative psychrophilic Psychrobacter immobilis B10. Biochim. Biophys. Acta 1993, 1171, 331-333.

117. Dong, D.; Ihara, T.; Motoshima, H.; Watanabe, K. Crystallization and preliminary X-ray crystallographic studies of a psychrophilic subtilisin-like protease Apal from Antarctic Pseudoalteromonas sp. strain AS-11. Acta Crystallogr. Sect. F Struct. Biol. Cryst. Commun. 2005, 61, 308-311. 
118. Chevrier, B.; Schalk, C.; D'Orchymont, H.; Rondeau , J.M.; Moras, D.; Tarnus, C. Crystal structure of Aeromonas proteolytica aminopeptidase: a prototypical member of the co-catalytic zinc enzyme family. Structure 1994, 2, 283-291.

119. Papaleo, E.; Pasi, M.; Tiberti, M.; De Gioia, L. Molecular dynamics of mesophilic-like mutants of a cold-adapted enzyme: Insights into distal effects induced by the mutations. PLOS ONE 2011, doi:10.1371/journal.pone.0024214.

120. Spiwok, V.; Lipovova, P.; Skalova, T.; Duskova, J.; Dohnalek, J.; Haaek, J.; Russell, N.J.; Kralova, B. Cold-active enzymes studied by comparative molecular dynamics simulation. J. Mol. Model. 2007, 13,485-497.

121. Miyazaki, K.; Wintrode, P.L.; Grayling, R.A.; Rubingh, D.N.; Arnold, F.H. Directed evolution study of temperature adaptation in a psychrophilic enzyme. J. Mol. Biol. 2000, 297, 1015-1026.

122. Kasana, R.C. Proteases from psychrotrophs: An overview. Crit. Rev. Microbiol. 2010, 36, 134-145.

123. Couto, G.H.; Glogauer, A.; Faoro, H.; Chubatsu, L.S.; Souza, E.M.; Margesin, F.O. Isolation of a novel lipase from a metagenomic library derived from mangrove sediment from the south Brazilian coast. Genet. Mol. Res. 2010, 9, 514-523.

124. Roh, C.; Villatte, F. Isolation of a low-temperature adapted lipolytic enzyme from uncultivated micro-organism. J. Appl. Microbiol. 2008, 105, 116-123.

125. Voget, S.; Steele, H.L.; Streit, W.R. Characterization of a metagenome-derived halotolerant cellulase. J. Biotechnol. 2006, 126, 26-36.

126. Sharma, S.; Khan, F.G.; Qazi, G.N. Molecular cloning and characterization of amylase from soil metagenomic library derived from Northwestern Himalayas. Appl. Microbiol. Biotechnol.2010, $86,1821-1828$.

127. Lee, C.C.; Kibblewhite-Accinelli, R.E.; Wagschal, K.; Robertson, G.H.; Wong, D.W.S. Cloning and characterization of a cold-active xylanase enzyme from an environmental DNA library. Extremophiles 2006, 10, 295-300.

128. Berlemont, R.; Pipers, R.; Delsaute, M.; Angiono, F.; Feller, G.; Galleni, M.; Power, P. Exploring the Antarctic soil metagenome as a source of novel cold-adapted enzymes and genetic mobile elements. Rev. Argent. Microbiol. 2011, 43, 94-103.

129. Tondo, E.C.; Lakus, F.R.; Oliveira, F.A.; Brandelli, A. Identification of heat stable protease of Klebsiella oxytoca isolated from raw milk. Lett. Appl. Microbiol. 2004, 38, 146-150.

130. Secades, P.; Alvarez, B.; Guijarro, J.A. Purification and characterization of a psychrophilic calcium induced, growth-phase dependent metalloprotease from the fish pathogen Flavobacterium psychrophilum. Appl. Environ. Microbiol. 2001, 67, 2436-2444.

131. Matta, H.; Punj, V. Isolation and partial characterization of a thermostable extracellular protease of Bacillus polymyxa B-17. Int. J. Food Microbiol. 1998, 42, 139-145.

132. Zhang, Y.; Porcelli, M.; Cacciapuoti, G.; Ealick, S.E. The crystal structure of 5'-deoxy-5'methylthioadenosine phosphorylase II from Sulfolobus solfataricus, a thermophilic enzyme stabilized by intramolecular disulfide bonds. J. Mol. Biol. 2006, 357, 252-262.

133. Storch, E.M.; Daggett, V.; Atkins, W.M. Engineering out motion: A surface disulfide bond alters the mobility of tryptophan 22 in cytochrome b5 as probed by time-resolved fluorescence and $1 \mathrm{H}$ NMR experiments. Biochem. 1999, 38, 5054-5064. 
134. Matthews, B.W.; Nicholson, H.; Becktel, W.J. Enhanced protein thermostability from sitedirected mutations that decrease the entropy of unfolding. P. Natl. Acad. Sci. USA 1987, 84, $6663-6667$.

135. D’Amico, S.; Claverie, P.; Collins, T.; Georlette, D.; Gratia, E.; Hoyoux, A.; Meuwis, M.A.; Feller, G.; Gerday, C. Molecular basis of cold adaptation. Philos. T. Roy. Soc. B. 2002, 357, 917925.

136. Boehr, D.D.; Dyson, H.J.; Wright, P.E. An NMR perspective on enzyme dynamics. Chem. Rev. 2006, 106, 3055-3079.

137. Henzler-Wildman, K.; Kern, D. Dynamic personalities of proteins. Nature 2007, 450, 964-972.

138. Tehei, M.; Zaccai, G. Adaptation to high temperatures through macromolecular dynamics by neutron scattering. FEBS J. 2007, 274, 4034-4043.

139. Adcock, S.A.; McCammon, J.A. Molecular Dynamics: Survey of methods for simulating the activity of proteins. Chem. Rev. 2006, 106, 1589-1615.

140. Van Gunsteren, W.F.; Bakowies, D.; Baron, R.; Chandrasekhar, I.; Christen, M.; Daura, X.; Gee, P.; Geerke, D.P.; Glattli, A.; Hunenberger, P.H. Biomolecular modeling: Goals, problems, perspectives. Angewandte Chemie International Edition in English 2006, 45, 4064-4092.

141. Van Gunsteren, W.F.; Dolenc, J.; Mark, A.E. Molecular simulation as an aid to experimentalists. Curr. Opin. Struc. Biol. 2008, 18, 149-153.

142. Pantoliano, M.W.; Whitlow, M.; Wood, J.F.; Dodd, S.W.; Hardman, K.D.; Rollence, M.L.; Bryan, P.N. Large increases in general stability for the subtilisin BPN' through incremental changes in the free energy of unfolding. Biochem. 1989, 28, 7205-7213.

143. Strausberg, S.L.; Alexander, P.A.; Gallagher, D.T.; Gilliland, G.L.; Barnett, B.L.; Bryan, P.N. Directed evolution of a subtilisin with calcium-independent stability. Biotechnology 1995, 13, $669-673$.

144. Shao, Z.; Zhao, H.; Giver, L.; Arnold, F.H. Random-priming in vitro recombination: An effective tool for directed evolution. Nucleic Acids Res. 1998, 26, 681-683.

145. Yang, Y.; Jiang, L.; Yang, S.; Zhu, L.; Wu, Y.; Li, Z. A mutant subtilisin E with enhanced thermostability. World J. Microb. Biot. 2000, 16, 249-251.

146. Siguroardottir, A.G.; Arnorsdottir, J.; Thorbjarnardottir, S.H.; Eggertsson, G.; Suhre, K.; Kristjansson, M.M. Characteristics of mutants designed to incorporate a new ion pair into the structure of a cold adapted subtilisin-like serine proteinase. Biochim. Biophys. Acta. 2009, 1794, $512-518$.

147. Narinx, E.; Baise, E.; Gerday, C. Subtilisin from psychrophilic antarctic bacteria: characterization and site-directed mutagenesis of residues possibly involved in the adaptation to cold. Prot. Eng.1997, 10, 1271-1279.

148. Zhao, H.; Arnold, F.H. Directed evolution converts subtilisin E into a functional equivalent of thermitase. Protein Engi. 1999, 12, 47-53.

149. He, H.L.; Chen, X.L.; Zhang, X.Y.; Sun, C.Y.; Zou, B.C.; Zhang, Y.Z. Novel Use for the Osmolyte Trimethylamine N-oxide, Retaining the psychrophilic characters of cold-adapted protease Deseasin MCP-01 and simultaneously improving its thermostability. Mar. Biotechnol. 2009, 11, 710-716. 
150. Vazquez, S.C.; MacCormack, W.P. Effect of isolation temperature on the characteristics of extracellular proteases produced by Antarctic bacteria. Polar Res. 2002, 21, 63-71.

151. Nielson, M.H.; Jepsen, S.J.; Outrup, H. Enzymes for lower temperature washing. J. Am. Oil Chem. Soc. 1981, 58, 644-649.

152. Pawar, R.; Zambare, V.; Barve, Z.; Paratkar, G. Application of protease isolated from Bacillus sp158 in enzymatic cleansing of contact lenses. Biotechnology 2009, 8, 276-280.

(C) 2013 by the authors; licensee MDPI, Basel, Switzerland. This article is an open access article distributed under the terms and conditions of the Creative Commons Attribution license (http://creativecommons.org/licenses/by/3.0/). 